\title{
Late Devonian and Early Carboniferous chondrichthyans from the Fairfield Group, Canning Basin, Western Australia
}

\author{
Brett Roelofs, Milo Barham, Arthur J. Mory, and Kate Trinajstic
}

\begin{abstract}
Teeth from 18 shark taxa are described from Upper Devonian to Lower Carboniferous strata of the Lennard Shelf, Canning Basin, Western Australia. Spot samples from shoal facies in the upper Famennian Gumhole Formation and shallow water carbonate platform facies in the Tournaisian Laurel Formation yielded a chondrichthyan fauna including several known species, in particular Thrinacodus ferox, Cladodus thomasi, Protacrodus aequalis and Deihim mansureae. In addition, protacrodont teeth were recovered that resemble formally described, yet unnamed, teeth from Tournaisian deposits in North Gondwanan terranes. The close faunal relationships previously seen for Late Devonian chondrichthyan taxa in the Canning Basin and the margins of northern Gondwana are shown here to continue into the Carboniferous. However, a reduction in species overlap for Tournaisian shallow water microvertebrate faunas between the Canning Basin and South China is evident, which supports previous studies documenting a separation of faunal and terrestrial plant communities between these regions by this time. The chondrichthyan fauna described herein is dominated by crushing type teeth similar to the shallow water chondrichthyan biofacies established for the Famennian and suggests some of these biofacies also extended into the Early Carboniferous.
\end{abstract}

Brett Roelofs. Department of Applied Geology, Curtin University, GPO Box U1987 Perth, WA 6845, Australia.brett.roelofs@postgrad.curtin.edu.au

Milo Barham. Department of Applied Geology, Curtin University, GPO Box U1987 Perth, WA 6845, Australia.milo.barham@curtin.edu.au

Arthur J. Mory. Geological Survey of Western Australia, Mineral House, 100 Plain Street, East Perth, WA 6004, Australia/Centre for Energy Geoscience, University of Western Australia, 35 Stirling Hwy, Crawley WA 6009, Australia. arthur.mory@dmp.wa.gov.au

Kate Trinajstic*. Department of Environment and Agriculture, Curtin University, GPO Box U1987, Perth, WA 6845, Australia. K.Trinajstic@curtin.edu.au *Corresponding author

Key words: Famennian; Tournaisian; microvertebrate; teeth; biogeography; biofacies

Submission: 2 July 2015 Acceptance: 25 November 2015

Roelofs, Brett, Barham, Milo, Mory, Arthur J., and Trinajstic, Kate. 2016. Late Devonian and Early Carboniferous chondrichthyans from the Fairfield Group, Canning Basin, Western Australia. Palaeontologia Electronica 19.1.4A: 1-28 palaeo-electronica.org/content/2016/1365-d-c-boundary-sharks 


\section{INTRODUCTION}

The Late Devonian saw an increase in the cosmopolitanism of many vertebrate taxa across parts of North and East Gondwana, and extending into South China and south-east Asia (Young et al., 2010). A shallow seaway along the northern margins of Gondwana is thought to have, at least in part, facilitated large scale faunal exchanges during this period (Lebedev and Zakharenko, 2010). At that time, the Canning Basin was located on the north-west corner of the East Gondwanan margin, which was contiguous with the North Gondwanan margin, with South China and southeast Asian landmasses further north (Golonka, 2007; Metcalfe, 2011). The Canning Basin was thus situated at the junction of major terranes and is therefore an ideal study area to evaluate Late Devonian faunal exchanges between these landmasses. Common faunal components between the Canning Basin and areas in South China and south-east Asia are known for several vertebrate groups from the Late Devonian, including placoderms (Young, 1984; Young et al., 2010) and chondrichthyans (Trinajstic and George, 2009; Roelofs et al., 2015). In addition, the jawless thelodonts are known from the uppermost Devonian in Iran (Hairapetian et al., 2015) North Gondwana and north-western Australia (Trinajstic, 2001; Hairapetian et al., 2015). Of these groups, only the sharks survived the Devonian-Carboniferous extinctions (Janvier, 1996). Whether the same chondrichthyan taxa persisted into the Carboniferous in intermediate regions between the Canning Basin and areas surrounding South China and the northern margin of Gondwana, is difficult to resolve. This is partly due to a significant faunal overturn in the Early Carboniferous with subsequent radiations of many groups including osteichthyans, chondrichthyans and tetrapods (Janvier, 1996; Sallan and Coates, 2010). In addition, Early Carboniferous tectonic movements, such as the northwards migration of the South China block, led to increased separation between this terrane and East Gondwana (Scotese and McKerrow, 1990).

Recent studies on Carboniferous shark faunas of Western Australia have been limited. Earlier works (Thomas, 1957, 1959) described a rich shark assemblage from the Lower Carboniferous Laurel Formation that included both "cladodont" and "bradyodont" teeth (for a review see Trinajstic et al., 2014). In addition, Turner (1982) described a species of ctenacanthiform, Cladodus thomasi Turner, 1982, and attributed associated teeth to the genus Helodus. Edwards (1997) detailed further chondrichthyan genera from a trench across the Devonian-Carboniferous boundary, approximately $45 \mathrm{~km}$ north-west of Fitzroy Crossing (Figure 1). Despite the paucity of published material, some similarity of the shark fauna between north-western and eastern Australia was recognised by Turner (1982). Here we aim to show the extent of the faunal links between the Canning Basin and the margins of Palaeo-Tethys along North and East Gondwana and southern Laurussia.

In addition to providing information on faunal ties, the rich chondrichthyan assemblage (Table 1), comprising 16 taxa from the Laurel Formation, allows a detailed analysis of a shark fauna from Tournaisian shallow water facies. The association between chondrichthyan taxa and the environments they inhabited has been analysed by Ginter $(2000,2001)$, who established three shark biofacies based on the percentages of shark teeth in Famennian pan-tropical regions. This biofacies model has been applied to a shallow water Famennian shark assemblage from the Canning Basin (Roelofs et al., 2015). Here we test if the Famennian shark biofacies model is applicable for the Carboniferous. This is in light of the Late Devonian mass extinction that caused significant niche reorganisations in which the placoderms, the dominant faunal component of the Devonian (Young, 2010) and the last of the thelodonts, which had survived into the Famennian only in Western Australia and Iran (Hairapetian et al., 2015), became extinct.

\section{GEOLOGICAL SETTING}

Extensive carbonate platforms with associated slope and basin facies developed along the northern margin of the Canning Basin, northern Western Australia from the late Givetian to late Famennian (Playford et al., 2009). Outcrops of these deposits extend along the Lennard Shelf for approximately $350 \mathrm{~km}$ and are amongst the world's best preserved examples of a Devonian reef complex (Hocking et al., 2008; Playford et al., 2009). Near the end of the Famennian an abrupt regression along the northern margin of the basin led to exposure, erosion and minor karstification of the reef platform prior to a change to ramp facies including carbonate, mudstone and sandstone, of the Fairfield Group (Druce and Radke, 1979; Southgate et al., 1993) (Figure 2). Along the southern, basin-ward margin of the Lennard Shelf and throughout much of the Fitzroy Trough, deposition of mostly fine-grained siliciclastic facies with minor carbonate appears to have been continuous into the Tournaisian. These southern basin-ward facies 


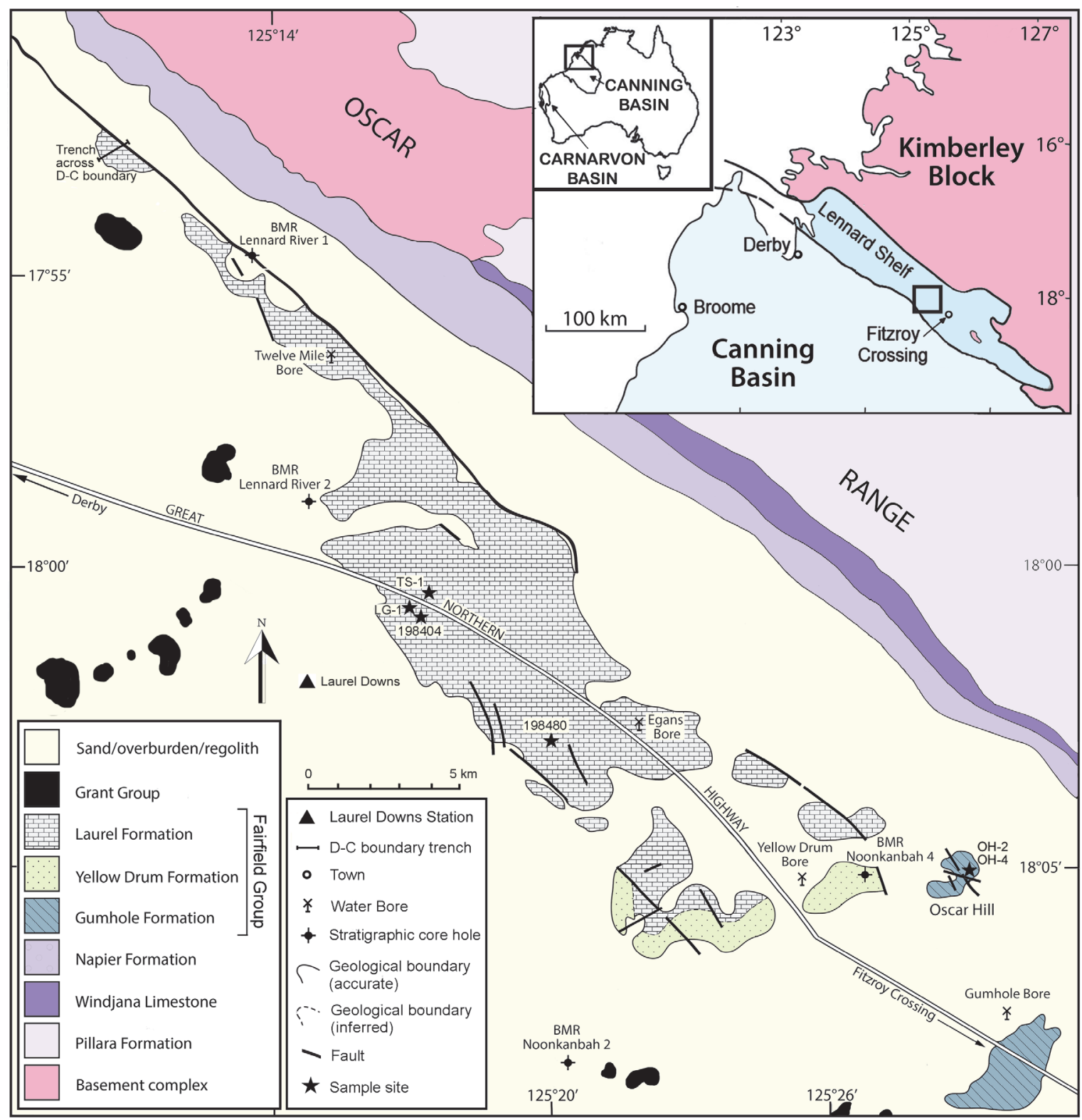

FIGURE 1. Simplified geological map of the Upper Devonian and Lower Carboniferous Fairfield Group outcrop, Lennard Shelf, northern Canning Basin, showing sampled sites at Oscar Hill and Laurel Downs (after Druce and Radke, 1979).

are only known from the subsurface and are largely attributed to the Upper Famennian Luluigui and Clanmeyer formations (Willmott, 1962). However, this part of the succession needs revision (Jones, 1987) given the somewhat arbitrary formation designations for petroleum wells in Druce and Radke (1979).

The oldest stratigraphic unit of the Fairfield Group, the Gumhole Formation, consists mostly of bioclastic and oolitic sandy limestone with interbedded carbonate, siltstone and shale. The formation is best exposed at Oscar Hill, approximately $19 \mathrm{~km}$ west-northwest of Fitzroy Crossing (Druce and Radke, 1979). Within the Horseshoe Range and Red Bluffs, the Gumhole Formation overlies a birdseye limestone likely to be the uppermost facies of the Nullara Limestone, whereas Druce and Radke (1979) and Edgell (2004) claim the Gumhole Formation overlies the Luluigui Formation in the Napier and Oscar Ranges. The overlying Yellow Drum Formation (Figure 2) consists of a series of massive calcareous sandstone and carbonate beds, with minor mudstone, breccia and evaporitic facies. 
TABLE 1. Distribution and abundance of Devonian and Carboniferous chondrichthyan teeth from the Lennard Shelf, Canning Basin, Western Australia.

\begin{tabular}{|l|c|c|c|c|c|c|}
\hline \multirow{2}{*}{$\begin{array}{r}\text { Taxa } \\
\text { Sample }\end{array}$} & \multicolumn{2}{c|}{$\begin{array}{c}\text { Oscar Hill } \\
\text { (Famennian) }\end{array}$} & \multicolumn{4}{c|}{ Laurel Downs } \\
\cline { 2 - 7 } & OH-2 & OH-4 & LG-1 & 198404 & 198480 & TS-1 \\
\hline Ageleodus sp. & - & - & - & 1 & - & 3 \\
\hline Phoebodus cf. turnerae & - & 1 & - & - & - & - \\
\hline Thrinacodus ferox & - & - & 5 & 8 & 12 & 9 \\
\hline Stethacanthus? sp. & - & - & - & 2 & - & - \\
\hline Cladodus thomasi & - & - & - & 4 & 1 & 8 \\
\hline Cladodoides cf. wildungensis & - & - & - & 3 & 1 & 2 \\
\hline Cladodontomorphi indet. sp. & - & - & - & - & 1 & - \\
\hline Ctenacanthiform gen. et sp. indet 1 & - & - & - & 3 & 1 & 4 \\
\hline Ctenacanthiform gen. et sp. indet 2 & - & - & - & - & - & 1 \\
\hline Protacrodus aequalis & - & - & - & - & - & 1 \\
\hline Protacrodus sp. 1 & - & - & - & - & - & 1 \\
\hline Deihim mansureae & 1 & - & - & 12 & 2 & 6 \\
\hline Dalmehodus cf. turnerae & - & - & 7 & 11 & - & 2 \\
\hline Protacrodontidae gen. et sp. indet & - & 1 & - & - & - & - \\
\hline Lissodus sp. & - & - & - & - & - & 1 \\
\hline Hybodontoidea gen. et sp. indet. & - & - & - & - & - & 1 \\
\hline Euselachii gen. et sp. indet & - & - & - & 6 & 2 & 9 \\
\hline Holocephali gen. et sp. indet. & - & - & - & 7 & - & 9 \\
\hline Total & & 2 & 12 & 57 & 20 & 57 \\
\hline & & & & & 146 & \\
\hline
\end{tabular}

The Devonian-Carboniferous boundary has been located in a trench $1 \mathrm{~km}$ northwest of Linesman Creek (Figure 1), excavated by researchers from Macquarie University, Sydney, Australia. In this section the boundary was placed at $7.5 \mathrm{~m}$ above the base of the Yellow Drum Sandstone based on the first appearance of the conodont Siphonodella sulcata Huddle, 1934. Unfortunately little data from the trench has been published apart from brief mentions by Andrew et al. (1994) and Burrow et al. (2010), the latter incorrectly indicating a location near Oscar Hill. The boundary also appears to lie within the Yellow Drum Formation in many petroleum wells, including near the base of BMR Noonkanbah 4 (Figure 1) based on palynomorphs (Playford, 1976) and conodonts (Nicoll and Druce, 1979); however, the position of the boundary in these sections is approximate at best.

A transgressive interval in the Early Carboniferous following deposition of the Yellow Drum Formation led to the development of lagoonal and shallow ramp facies of the Laurel Formation, the uppermost unit of the Fairfield Group (Figure 2). The formation is poorly exposed in a $2-10 \mathrm{~km}$ wide belt southwest of the Napier and Oscar Ranges, with somewhat better exposures in the vicinity of Twelve Mile Bore. The Laurel Formation is characterised by a series of interbedded fossiliferous calcarenite, siltstone, sandstone and minor dolomitic beds, and contains a diverse fauna including bryozoans and corals (Thomas, 1959), foraminifera (Edgell, 2004), ostracods (Jones, 1959, 1974), rare ammonoids (Glenister and Klapper, 1966) and fish (Thomas, 1957, 1959; Turner, 1982; Long, 1989; Burrow et al., 2010). Studies of the brachiopod (Veevers, 1959; Thomas, 1971) and conodont (Glenister and Klapper, 1966; Nicoll and Druce, 1979) faunas indicate a general Tournaisian age, later revised to early to mid-Tournaisian by Jones (1995).

\section{MATERIALS AND METHODS}

The examined teeth were extracted from $5 \mathrm{~kg}$ rock samples collected in 2012 from carbonate beds exposed at Oscar Hill and on Laurel Downs Station, Canning Basin, Western Australia (Figure 1). Samples were dissolved in buffered acetic acid 


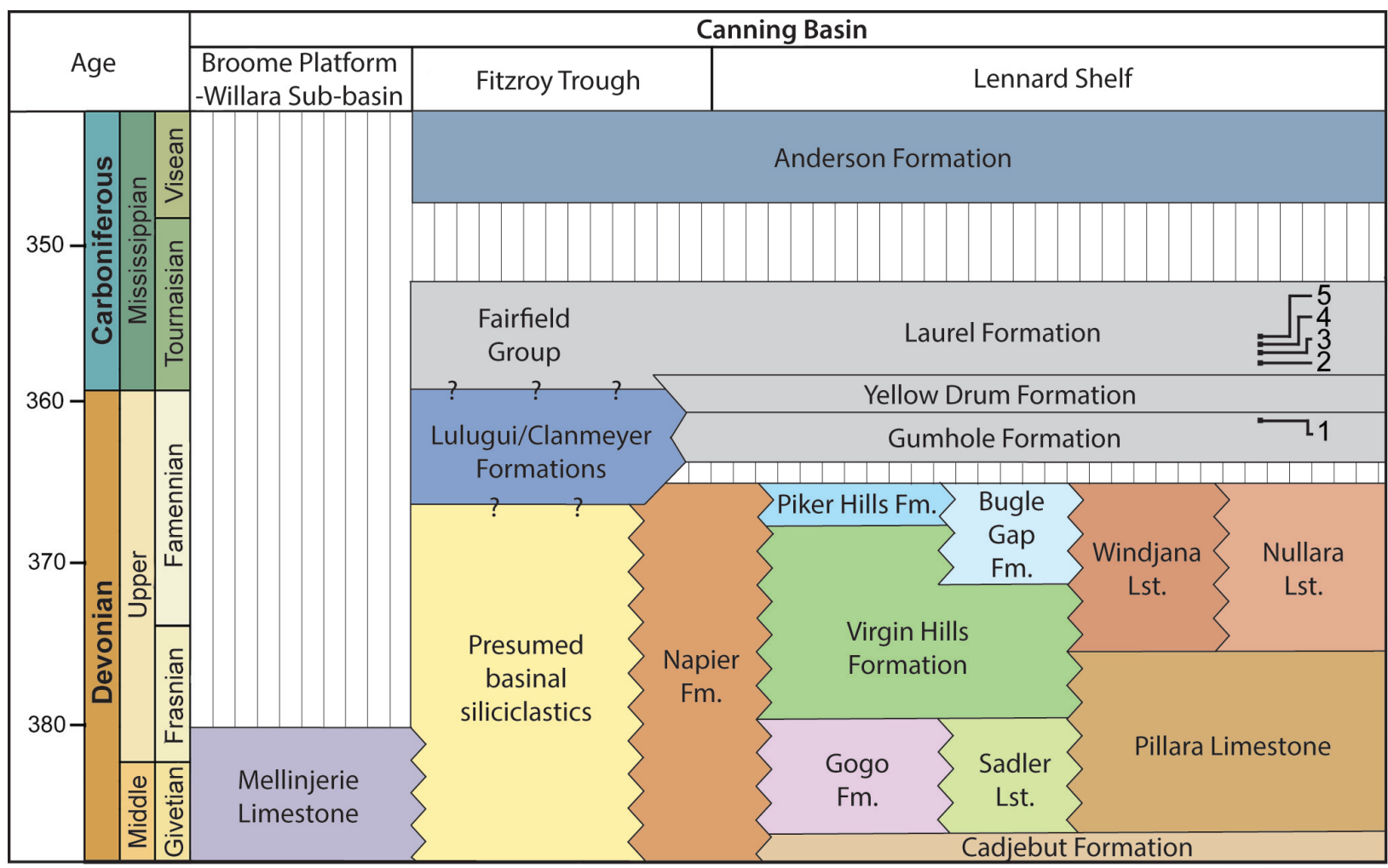

FIGURE 2. Stratigraphy and correlation of Upper Devonian and Lower Carboniferous units of the Lennard Shelf (after Smith et al., 2013). Approximate temporal positions of the sampled localities: 1, OH4; 2, 198480; 3, 198404; 4, LG-1; and 5, TS-1. Abbreviations: Fm, Formation; and Lst, Limestone.

following the methodology of Jeppsson et al. (1999). Residues were subsequently washed and sieved (mesh size of $0.250 \mathrm{~mm}$ ) before being picked under a Nikon stereomicroscope.

Teeth used for imaging under a scanning electron microscope (SEM) were adhered to carbon tabs on $10 \mathrm{~mm}$ aluminium stubs. The mounted fossils were then coated with $10 \mu \mathrm{m}$ platinum and imaged using a Zeiss Evo 40XVP SEM at the Centre for Materials Research at Curtin University. A Hitachi TM-3030 desktop SEM at the Department of Applied Geology (Curtin University) was also used for imaging fragile teeth. Imaging was undertaken using accelerating voltages ranging from 5 to $15 \mathrm{kV}$ under variable pressure.

The standard conodont zonation of Ziegler and Sandberg (1990) cannot be readily applied to the Famennian shallow water facies in the Canning Basin due to the dominance of polygnathids and paucity of palmatolepids (Klapper, 2007; Mory and Hocking, 2011). However, it is possible to indirectly correlate the succession at Oscar Hill to the standard conodont zones (CZ) using ammonoids (Becker and House, 2009). Similarly, the Carboniferous conodont zonation of Nicoll and Druce
(1979) is dominated by shallow-water conodont genera, the ranges of which are strongly tied to local facies, and so do not provide a direct correlation to the standard zonation. According to Jones (1995), the conodont faunas from the Laurel Formation do not extend above the range of Siphonodella (Tn 1-2) in spite of the paucity of that genus.

All microvertebrate specimens are housed in the Western Australian Museum (WAM).

\section{Sample Localities}

Oscar Hill. Two samples $(\mathrm{OH} 2, \mathrm{OH} 4)$ were taken in 2012 from large cross stratified, sandy oolitic grainstone beds at the base of Oscar Hill (Figure 1, $\left.18^{\circ} 04^{\prime} 07^{\prime \prime} \mathrm{S}, 125^{\circ} 26^{\prime} 41^{\prime \prime} \mathrm{E}\right)$, approximately 15 $\mathrm{km}$ north west of Fitzroy Crossing. That section consists mainly of ooidal and bioclastic sandstone deposited within a shoal environment (Druce and Radke, 1979). Previous work at Oscar Hill documented a diverse fauna including ostracods (Jones and Thomas, 1959), brachiopods (Veevers, 1959), goniatites (Teichert, 1949), corals (Hill, 1954) and bryozoans (Ross, 1961). Numerous crinoid, 
bivalves, and gastropod fossils have also been identified (Druce and Radke 1979) but are yet to be described. Conodont faunas (Nicoll and Druce, 1979; West Canning Basin [WCB] section 002) place the section within the Devonian Icriodus platys Assemblage Zone (A.Z.), equivalent to the praesulcata conodont zone of Ziegler and Sandberg (1990). A range of vertebrate material has been reported from the Oscar Hill area including arthrodire plates (Druce and Radke, 1979) and dipnoan remains (Young, 1987). Shark teeth have been previously found in the area (Edwards, 1997 unpublished thesis; Burrow et al., 2010) with some beds yielding abundant orodont teeth.

Laurel Downs. Exposure of the Lower Carboniferous Laurel Formation on Laurel Downs station (Figure 1) is poor and largely confined to thin shallowly dipping limestone beds. Muddy intervals are weathered and covered by black soil. Determining detailed stratigraphic relationships between sections is hindered by poor exposure and numerous faults. Spot samples from thickly bedded, fossiliferous silty boundstone contain intact bryozoans, brachiopods and tabulate corals (Sample 198404, Figure 1 , locality $\left.18^{\circ} 01^{\prime} \mathrm{S}, 125^{\circ} 18^{\prime} \mathrm{E}\right)$. Samples TS-1 (Figure $1,18^{\circ} 01^{\prime} \mathrm{S}, 125^{\circ} 17^{\prime} \mathrm{E}$ ), 198480 (Figure $1,18^{\circ} 02^{\prime} \mathrm{S}, 125^{\circ} 20^{\prime} \mathrm{E}$ ) and LG-1 (Figure 1, $\left.18^{\circ} 01^{\prime} \mathrm{S}, 125^{\circ} 19^{\prime} \mathrm{E}\right)$ were extracted from a series of sandy bioclastic grainstone beds containing a rich ichthyolith fauna as well as minor, disarticulated brachiopod valves and crinoid ossicles. Conodonts from sample 198404 include Bispathodus aculeatus plumulus Rhodes, Austin, and Druce, 1969 and Clydagnathus cavusformis Rhodes, Austin, and Druce, 1969, indicating an Early Carboniferous age.

\section{SYSTEMATIC PALAEONTOLOGY}

\author{
Class CHONDRICHTHYES Huxley, 1880 \\ Family INCERTAE SEDIS \\ Genus AGELEODUS Owen, 1867
}

Type Species. Ctenopychius pectinatus Agassiz, 1838

Ageleodus sp.

Figure 3.1-4

Material. Four incomplete teeth: one tooth from sample 198404, and three teeth from TS-1, Laurel Formation, Laurel Downs, Tournaisian.

Description. Labio-lingually compressed crown that is slightly arched along the occlusal margin (Figure 3.1-3). The crown comprises a single row of four to five unornamented triangular cusps, decreasing in size distally (Figure 3.1). Most teeth bear cusp apices with a slight lingual inclination that are typically worn flat or slightly rounded (Figure 3.2-3). One specimen, WAM 15.6.33, (Figure 3.4) preserves three pointed triangular cusps with little wear. Shallow, vertical grooves originating at the juncture of the cusps are present on the top half of both crown faces. On one tooth (WAM 15.6.34, Figure 3.2), the crown is labio-lingually convex between the base of the cusps and the crown base interface. The lateral sides of the crown are rounded and taper mesially to a shallow depression along the crown-base interface (Figure 3.1-3). The labio-lingually flattened base is short and bears small foramina and longitudinal furrows.

Remarks. Due to the high level of heterodonty previously recorded for Ageleodus pectinatus Agassiz, 1838 and the absence of multiple complete teeth from the samples, species determination is not possible. The teeth do share similarities with other known Ageleodus species. One partial tooth crown (WAM 15.6.33, Figure 3.4) possesses the pointed triangular cusps typical of the Late Devonian Ageleodus pectinatus Downs and Daeschler, 2001 and the Ageleodus teeth described by Lebedev (1996, figure 13). The rounded apicies on one tooth (WAM 15.6.23, Figure 3.1) are similar to Ageleodus altus Garvey and Turner, 2006 from the Carboniferous of Victoria, Australia. As cusp morphology appears to diagnose different species of Ageleodus, it is possible more than one species inhabited the Canning Basin at this time. However, given the large amount of variation in the small sample size, it is more likely physical wear has contributed to the cusp shape than species specific morphology.

Subclass ELASMOBRANCHII Bonaparte, 1838 Order PHOEBODONTIFORMES Ginter, Hairapetian and Klug, 2002

Family PHOEBODONTIDAE Williams, 1985 Genus PHOEBODUS St. John and Worthen, 1875

Type Species. Phoebodus sophiae St. John and Worthen, 1875

\section{Phoebodus cf. turnerae}

Figure 3.5-7

Material. One tooth from sample $\mathrm{OH}-4$, Gumhole Formation, Oscar Hill, Famennian.

Description. Tooth with incomplete crown, comprising a single medial cusp flanked by two mesiodistally diverging lateral cusps (Figure 3.5-6). The central cusp is broken with a faint sub ovoid basal outline (Figure 3.5). The lateral cusps are rounded along the lingual margins and flattened on the labial face. Faint vertical striations are preserved on the basolabial face of one cusp (Figure 3.6). 


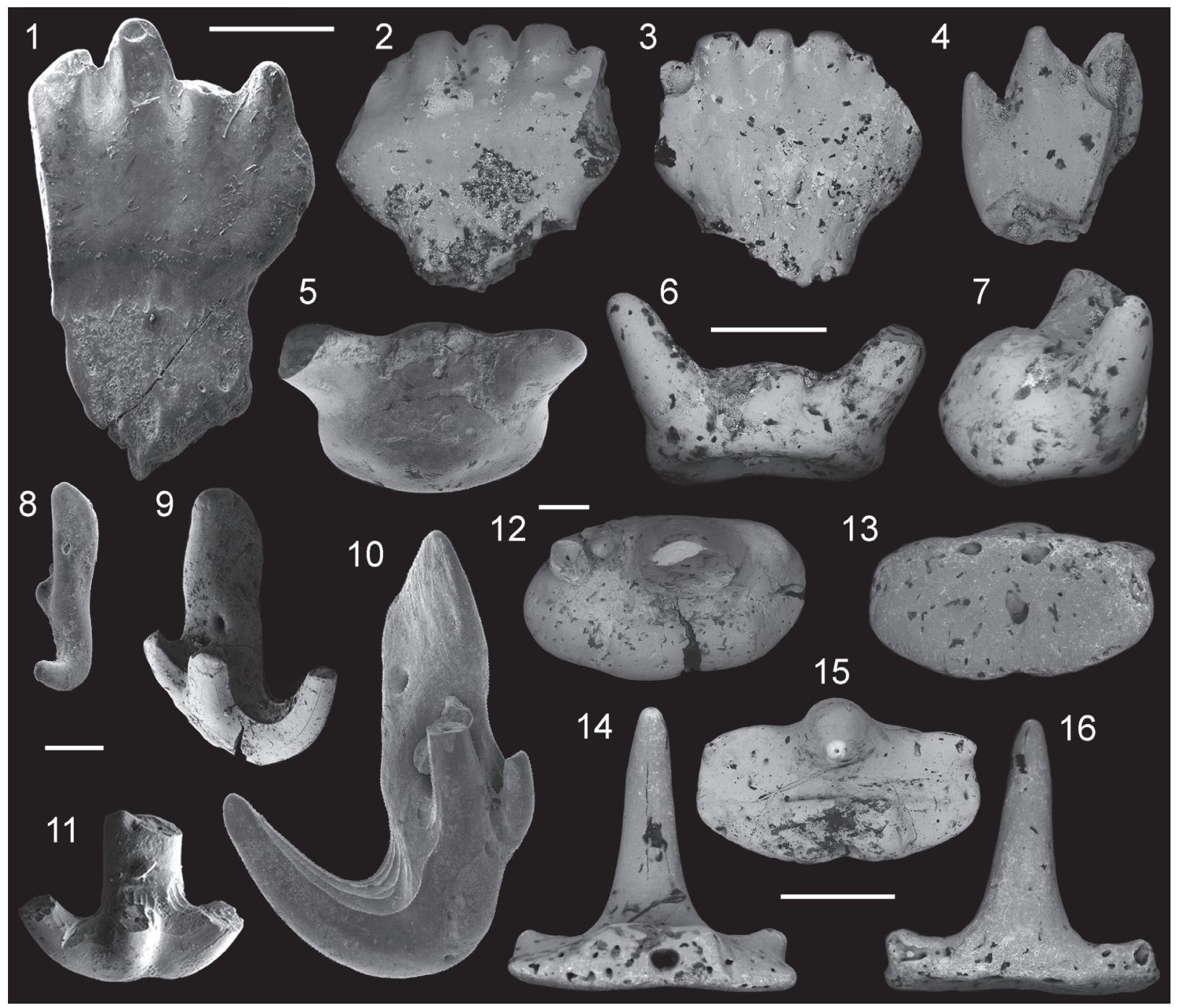

FIGURE 3. Late Devonian and Early Carboniferous shark teeth from the Lennard Shelf, Canning Basin, Western Australia. 1-4, Ageleodus sp., WAM 15.6.23, sample 198404, in lingual view (1), WAM 15.6.34, sample TS-1, in labial (2) and lingual (3) views, and WAM 15.6.33, sample TS-1, in lingual view (4); 5-7, Phoebodus cf. turnerae, WAM 15.6.28, sample $\mathrm{OH}-4$, in occlusal (5), labial (6) and lateral (7) views; 8-11, Thrinacodus ferox, WAM 15.6.32, sample LG-1, in occlusal view (8), WAM 15.6.8, sample 198404, in occlusal view (9), WAM 15.6.11, sample 198404, in lateral view (10), and WAM 15.6.9, sample 198404, in occlusal view (11); 12-16, Stethacanthus? sp., WAM 15.6.6, sample 198404, in occlusal view (12), and WAM 15.6.7, sample 198404, in basal (13), lingual (14), occlusal (15) and

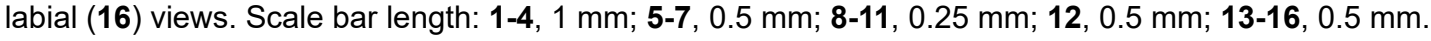

The base is sub-rectangular in outline with wellrounded margins (Figure 3.7). A large lenticular button, with a single medially located canal, is positioned centrally on the lingual face of the base and extends between the mesial margins of the lateral cusps (Figure 3.5). The labial face of the base is thickened and borders a well-developed concave under-surface.

Remarks. This tooth resembles Phoebodus turnerae Ginter and Ivanov, 1992 in having a rounded, lingually extended base and hemispherical button perforated by a large canal along its lingual face.
The thin, sub-parallel cristae diagnostic of this species are not clearly recognisable on this tooth; however, faint ornament is present on the baso-labial face of the broken lateral cusp (Figure 3.6). The rounded nature of the tooth and low relief of the button may be due to abrasion consistent with the high energy shoal facies from which this tooth was recovered. The current upper age range for $P h$. turnerae is from the lower (crepida CZ) to middle (marginifera CZ) Famennian (Ginter et al., 2010) whereas the Oscar Hill area is dated as latest Famennian (Nicoll and Druce, 1979), and suggests 
either the tooth does not belong to Ph. turnerae, or the range of $P h$. turnerae extends into the late Famennian in the Canning Basin. Further phoebodont teeth need to be recovered, along with more precise age constraints, before the taxonomy of this tooth can be resolved.

Genus THRINACODUS St. John and Worthen, 1875

Type Species. Thrinacodus nanus St. John and Worthen, 1875

Thrinacodus ferox (Turner, 1982)

Figure 3.8-11

v. 1982 Harpago ferox sp. nov.; Turner, pp. 119, 121-122, figs. 2-4.

v. 1985 Harpagodens ferox Turner; Wang and Turner, pp. 226-227, pl. 2, figs. 11-12.

v. 1989 Harpagodens ferox Turner; Wang, pp. 105-106, pl. 28 , figs. $6-7$, pl. 29 , fig. $2 a$, b, pl. 30, figs. 1-4.

v. 1991 Thrinacodus (Harpagodens) ferox Turner; Turner, fig. 6, pl. 2, fig. G.

v. 1992 cf. Thrinacodus ferox Turner; Kietzke and Lucas, p. 18, fig. 2D-H.

v. 1993 Thrinacodus ferox Turner; Turner, fig. 8.7F.

v. 1996 Thrinacodus ferox Turner; Ginter and Ivanov, p. 267, figs. $1,2 \mathrm{C}-\mathrm{D}$.

v. 1999 Thrinacodus ferox Turner; Ginter, p. 34, pl. 3 , figs. 1-3, 5-7.

v. 1999 Thrinacodus sp.; Ivanov, p. 273, pl. 4, figs. 2-4.

v. 2001 Thrinacodus ferox Turner; Ginter, p. 719, figs. 3C-E, 4A-C.

v. 2003 Thrinacodus incurvus; Duncan, pp. 119120 , figs. $5-6$.

v. 2010 Thrinacodus ferox Turner; Ginter and Turner, p. 1669, fig. 3A-H.

v. 2010 Thrinacodus ferox Turner; Ginter, Hampe and Duffin, p. 41, fig. 33B-F.

v. 2011 Thrinacodus ferox Turner; Habibi and Ginter, pl.1, fig. A-B.

v. 2011 Thrinacodus ferox Turner; Ivanov and Lucas, p. 55, fig. 3A-L.

v. 2012 Thrinacodus ferox Turner; Behan, Walken and Cuny, p. 1249, fig. 3A-M.

Material. Eight teeth from sample 198404, 12 from TS-1, and nine teeth from sample LG-1, Laurel Formation, Laurel Downs, Tournaisian.

Description. Tricuspidate teeth with symmetrical (Figure 3.11 ) to highly asymmetrical forms (Figure
3.10). All cusps are strongly inclined lingually, circular in cross section and typically bear faint striations on both lingual and labial faces. The symmetrical tooth form (WAM 15.6.9, Figure 3.1011 ) is incomplete but comprises a crown and three cusps with equally sized basal circumferences. Asymmetrical teeth comprise one enlarged lateral cusp, a second medial cusp approximately onethird to two-thirds its size and the third smaller lateral cusp varying from a quarter of the size of the central cusp to equal in proportion. The tooth base is elongate lingually and when preserved, shows a greater than 45 degrees of torsion towards the distal end of the base. A large canal is present on the occlusal face of the base (Figure 3.8-11) with a few smaller foramina on both the lingual and labial faces of the base (Figure 3.10).

Remarks. We consider both the symmetric and asymmetric teeth to be from the one species due to the gradation from symmetric to asymmetric forms recovered from the sample. The presence of just one symmetrical tooth (Figure 3.11 ) supports Turner's (1982, figure 5) reconstruction of the Thinacodus ferox Turner, 1982 jaw placing the symmetrical forms in a symphyseal position of the jaw and the asymmetric teeth in more lateral positions. The teeth with lower degrees of symmetry (Figure 3.9) were not figured in the original description (Turner, 1982) but appear similar in form to end member teeth figured in a reconstruction of Thrinacodus incurvus Newberry and Worthen, 1866 by Duncan (2003).

Among the teeth attributed to Th. ferox, are six significantly smaller teeth. These teeth typically have a well-formed base; however, the cusps are shorter than in larger specimens and bear wellrounded apices (Figure 3.8). It is possible the teeth belong to juvenile specimens and the susceptibility to wear contributed to the well-rounded cusps.

Distribution and stratigraphic range. In Australia Th. ferox is recorded from the latest Famennian in Queensland (Turner, 1982) and Tournaisian in both the Canning and Carnarvon basins of Western Australia (Trinajstic et al., 2014) and New South Wales (Turner, 1982). Globally, Th. ferox is known from the Famennian in southern China (Wang, 1993), Germany (Ginter, 1999), Morocco (Derycke, 1992; Derycke et al., 2008) and Utah, USA (Ginter, 2001). Teeth have also been recorded around the Devonian-Carboniferous boundary in New Mexico, USA (Kietzke and Lucas, 1992). Thrinacodus ferox is known from the Mississippian in the South Urals and Moscow syncline Russia (Ivanov, 1996), Bel- 
gium (Delsate et al., 2003), Ireland (Duncan, 2003).

\section{Superorder CLADODONTOMORPHI Ginter, Hampe and Duffin, 2010 \\ Order SYMMORIFORMES Zangerl, 1981 \\ Family STETHACANTHIDAE Lund, 1974 \\ Genus STETHACANTHUS Newberry, 1889 \\ Stethacanthus? sp. \\ Figure 3.12-16}

Material. Two teeth from sample TS-1, Laurel Formation, Laurel Downs, Tournaisian.

Description. The description is primarily based on the most intact specimen (WAM 15.6.7, Figure 3.12-16) in which the tooth crown includes three (Figure 3.14-16) to four cusps (Figure 3.12). The tooth possesses a distinct and highly elongate medial cusp with a basal width occupying approximately one-third of the mesio-distal length crown (Figure 3.14-16). Two small, rounded lateral cusps are directed approximately 45 degrees from the centre of the tooth. The larger specimen (WAM 15.6.6, Figure 3.12) bears a single smaller, laterally-divergent cusplet between the medial and lateral cusp. The cusps are relatively smooth apart from very faint vertical ridges on specimen WAM 15.6.7 (Figure 3.16). In the smaller specimen (WAM 15.6.7) the base extends lingually beyond the crown and is roughly rectangular in outline (Figure 3.15). The lingual margin is rounded with a small central indentation. The lateral margins of the base extend furthest at the corner of the lingual margin. In the larger specimen the base is asymmetrical, having a roughly ovoid outline (Figure 3.12). A distinct crown-base interface is lacking on the labial face of the tooth (Figure 3.16) with only a slight thickening along the baso-labial margin. An ovoid button, approximately the same width as the base of the central cusp (Figure 3.14), is located close to the lingual margin of the tooth base. A large canal opening is positioned in the centre of the button (Figure 3.14) with the opposing end on the underside of a very shallow concave base (Figure 3.13).

Remarks. Stethacanthid affinities are suggested by the elongate and thin, biconvex central cusp, the lack of a baso-labial depression (with slight labial projection under the main cusp) and a large foraminal opening on the lingual face of the orolingual button (Duffin and Ginter, 2006). Furthermore, the larger tooth, which bears a single intermediate cusplet, suggests some of the teeth belonging to this species may be pentacuspid.
Order CTENACANTHIFORMES Glikman, 1964

Family CTENACANTHIDAE Dean, 1909

Genus CLADODUS Agassiz, 1843

Cladodus thomasi Turner, 1982

Figure 4.1-7

v. 1959 "Cladodont"; Thomas, p. 36, fig. 4a.

v. 1982 Cladodus thomasi sp. nov.; Turner, pp. 125,127 , figs. $6 \mathrm{C}, 7 \mathrm{~J}$.

Material. Four teeth from sample 198404, two teeth from sample 198480, eight teeth from TS-1, Laurel Formation, Laurel Downs, Tournaisian.

Revised diagnosis. Teeth with nine cusps; a large central cusp, a pair of large lateral cusps and three smaller pairs of intermediate cusplets (Figure 4.14). The central cusp is the largest followed by the outer cusps, which diverge in a slight distal direction. The first and third lateral cusps are small, approximately a quarter to one-third the size of the lateral cusps (Figure 4.5). The second pair of intermediate cusplets are almost equal in size to the outer lateral cusps. Converging ridges are present on the base of the main cusp (Figure 4.7) whereas the lateral cusps all bear strong, non-bifurcating ridges (Figure 4.6-7). The central cusp bears a slight depression along the baso-labial face and is rounded along the lingual face. A secondary row of small labial cusplets is present on the crown base of larger teeth (Figure 4.6-7). The basal outline is lozenge shaped in smaller teeth (Figure 4.2) becoming trapezoid in larger specimens (Figure 4.6). An elongate oro-lingual button bearing four canal openings abuts the lingual margin. Small foramina accompany the pore canals on the lingual and the occlusal surface of the oro-lingual button. A row of small foramina also occur within an arched groove on the labial surface immediately below the crown-base interface (Figure 4.4, 4.7). A baso-labial shelf extends between the first set of lateral cusplets and is slightly thickened at the distal edges (Figure 4.4, 4.7). A shallow depression is present on the labial underside of the base, which also bears multiple canal openings. The lingual portion of the base is flattened under the oro-lingual button but may be flared occlusally along the distal edges of the lingual margin (Figure 4.1, 4.3).

Description. Teeth range in size from $2.2 \mathrm{~mm}$ to $90 \mathrm{~mm}$ in length, mesio-distally. The crown includes a prominent triangular central cusp, which is flattened to depressed along the labial margin and convex along the lingual face (Figure 4.6). A pair of lateral cusps and three pairs of intermediate cusplets flank both sides of the medial cusp. The outermost cusps are the largest and approximately one quarter larger than the second lateral cusplets. 


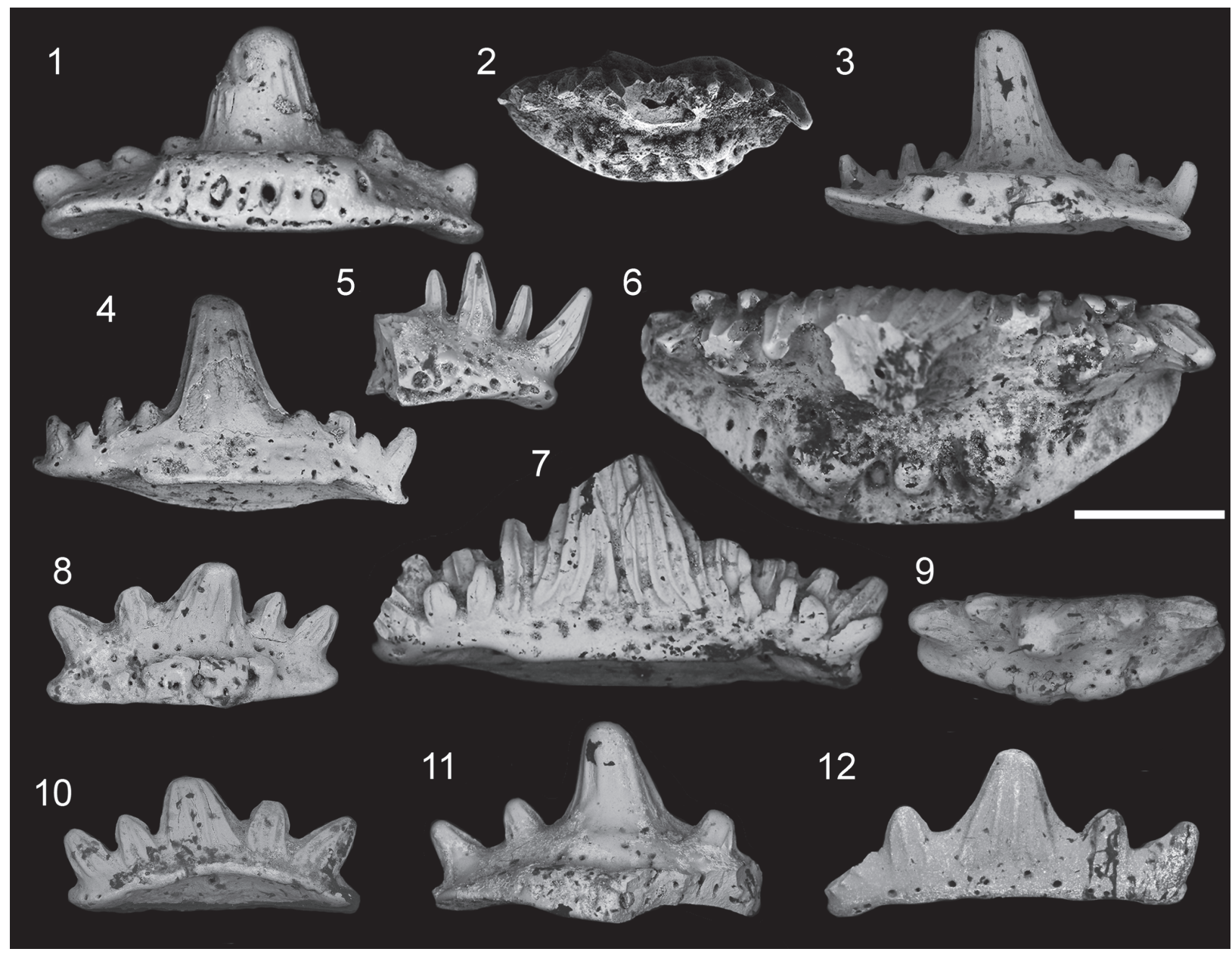

FIGURE 4. Ctenacanthiform teeth from the Lower Carboniferous Laurel Formation, Laurel Downs, Lennard Shelf, Canning Basin, Western Australia. 1-7, Cladodus thomasi, WAM 15.6.50, sample 198404, in lingual view (1), WAM 15.6.25, sample 198404, in occlusal view (2), WAM 15.6.12, sample 198404, in lingual (3) and labial views (4), WAM 15.6.19, sample 198404, partial platform and crown in lingual view (5), and WAM 15.6.13, sample TS-1, in occlusal (6) and labial (7) views; 8-12, Cladodoides cf. wildungensis, WAM 15.6.15, sample 198404, in lingual (8), occlusal (9) and labial (10) views, WAM 15.6.16, sample 198404, in labial (11) and lingual (12) views. Scale bar length: 1-7, $1 \mathrm{~mm}$; 8-10, $0.25 \mathrm{~mm} ; 11-12,0.5 \mathrm{~mm}$

The first and third pairs of intermediate cusplets are of smaller size, ranging from a quarter to half the size of the lateral cusps (Figure 4.3, 4.5). Prominent, non-bifurcating ridges are present on both the labial and lingual faces of each lateral cusp. Larger specimens (Figure 4.6-7) show a small row of cusplets along the baso-labial face of the crown. Small teeth show a more lenticular outline to the base (Figure 4.2). A roughly trapezoid basal outline with rounded edges (Figure 4.6) is present in larger specimens. An elongate ovoid button, extending between the inner margins of the second pair of lateral cusps, is positioned close to the lingual rim and is perforated by four canal openings on the lingual face. A small baso-labial shelf, between the first lateral cusps, borders an often weakly developed baso-labial depression below the central cusp (Figure 4.4).

Remarks. The original diagnosis of Cladodus thomasi Turner, 1982 was based on a small tooth from the Upper Bundock Formation, Queensland (Holotype UQG F73007) as well as a tooth partially obscured by matrix (Thomas, 1959, figure 4a) collected from the Laurel Formation in the vicinity of Twelve Mile Bore (Figure 1). The teeth recovered here, also collected from the Laurel Formation, conform to the original diagnosis for this species in addition to providing further diagnostic characters which allow for these teeth to be reassigned to the genus Cladodus. The central cusp morphology of $C$. thomasi, with its flattened labial face and convex lingual surface (Figure 4.6), is quite different to the 
biconvex cusp-type in Stethacanthus. Cladodus thomasi is further differentiated from Stethacanthus by multiple intermediate cusps. The baso-labial shelf and elongate oro-lingual ridge, typical of the genus Cladodus, are also found in C. thomasi.

The new specimens of $C$. thomasi from the Canning Basin have highlighted previously undescribed variation in tooth morphology. Differences are typically seen in the basal outline with smaller teeth possessing a more lozenge shaped outline that becomes more trapezoid in form as the size of the tooth increases. Further variation is present in some of the larger teeth (Figure 4.6-7) which bear a second small row of labial cusplets. These accessory cusplet rows are also found in other Carboniferous ctenacanthiform teeth such as Tamiobatis vetustus Eastman, 1897 (Williams, 1998, figure 5A-B) and Saivodus striatus Agassiz, 1843 (Ginter et al., 2010, figure 72A-B).

Several Famennian cladodont teeth, possessing a single intermediate cusplet, were previously attributed to "Stethacanthus" thomasi (Derycke, 1992, plate 2:10-11; Hampe, 2000, plate 2:1-4). Given the morphological variation and large number of teeth, it is clear the teeth of $C$. thomasi possess three sets of intermediate cusplets, independent of the tooth size. This suggests the teeth figured in Derycke (1992) and Hampe (2000) are unlikely those of $C$. thomasi but instead belong to another ctenacanthiform shark. The tooth (MCD 177) formally figured by Derycke (1992, figure 14 , plate 2: 10,11$)$ was synonymised firstly with Stethacanthus resistens Ginter, 2002 and then with Cladodoides wildungensis by Ginter et al., (2010), who also suggested many of the teeth formally attributed to "Stethacanthus thomasi" belong to $C$. wildungensis.

Cladodus thomasi was considered as a junior synonym of Stethacanthus obtusus Trautschold, 1874 by Lebedev (1996); however, Hampe (2000) noted $S$. obtusus had a greater number of cusps than $C$. thomasi in addition to more foramina along the edge of a less distinguished button and therefore the species determination of $S$. thomasi was retained. The holotype of $C$. thomasi (Turner, 1982, figure $6 \mathrm{C}$ ) is an asymmetric tooth possessing eight cusps. The newly recovered teeth of $C$. thomasi indicate the possession of nine cusps is common for these teeth, similar to $S$. obtusus. The lingual button appears more developed in $C$. thomasi, as noted by Hampe (2000) and typically possesses four large foramina on the lingual face. In comparison, $S$. obtusus is described as possessing two to six large foramina. The larger forms of $C$. thomasi, comparable in size to $S$. obtusus figured by Lebedev (1996), possess a distinct secondary row of cusplets along the labial face of the tooth, a feature lacking in the 40 specimens of $S$. obtusus. Further distinguishing $C$. thomasi from the Canning Basin is the shape of the base, which takes on a more trapezoid form in larger specimens compared to the lozenge shape seen in S. obtusus. The basolabial shelf is also more elongate in $S$. obtusus, than $C$. thomasi, extending to the medial cusplets. In $C$. thomasi the baso-labial shelf only extends between the distal margins of the first pair of intermediate cusplets. We believe these differences are sufficient for $C$. thomasi to be retained as a distinct species.

We note there are similarities between the teeth, designated here as $C$. thomasi and Tamiobatis sp. (Ginter and Sun, 2007) from Muhua, south China, including the presence of three pairs of intermediate lateral cusplets, that alternate in height, as well as a basal outline, which extends lingually furthest in front of the lingual button. However, the teeth from the Canning Basin are distinct in that they lack a small lateral cusplet often present in the teeth from Muhua and have a far more angular basal outline. The teeth of Tamiobatis sp. (Ginter and Sun, 2007) also lack the row of accessory labial cusplets despite being of comparable size to the teeth of $C$. thomasi. Another member of the genus, Tamiobatis vetustus Eastman, 1897 (Williams, 1998), is known for the presence of labial cusplets, however they are present behind the main cusp, a feature not found in the teeth of $C$. thomasi (Figure 4.7). Although there are some features of the genus Tamiobatis, which are present in the teeth of $C$. thomasi, the greater number of morphological differences precludes these teeth from being assigned to Tamiobatis.

Distribution and stratigraphic range. Given the revised diagnosis, $C$. thomasi is restricted to the Lower Carboniferous of Australia. Teeth have been recovered from the Lower Carboniferous upper Bundock Formation, North Queensland and from the Tournaisian Laurel Formation, Canning Basin, Western Australia.

\section{Cladodoides cf. wildungensis}

Figure 4.8-12

Material. Three teeth from sample 198404, one tooth from sample 198480, two teeth from sample TS-1, Laurel Formation, Laurel Downs, Tournaisian.

Description. The pentacuspid crown comprises a large triangular central cusp with a pair of distally diverging lateral cusps and small (approximately 
two thirds the size of the lateral cusps) intermediate cusplets (Figure 4.8-12). Cusp faces are ornamented in coarse, predominantly parallel ridges converging toward the cusp apex (Figure 4.8, 4.12). The labial face of the central cusp is flattened with a slight baso-labial depression. The base is lenticular in outline (Figure 4.9) and extends furthest in front of the central cusp. The crown-base interface is marked by a low arch along the labial face (Figure 4.8). The lateral end of the base extends beyond the crown in most specimens; however, this is significantly less extended in one specimen (Figure 4.12) A row of small pores is present along the crown base interface on the labial side. An ovoid button extends between the distal margins of the intermediate cusplets and is positioned centrally along the occlusal edge of the baso-lingual rim. The baso-labial thickening lies between the intermediate cusps and does not protrude far lingually (Figure 4.10, 4.12).

Remarks. The teeth bear a resemblance to the teeth originally described as Stethacanthus resistens by Ginter (2002) and later synonymised with Cladodoides wildungensis Jaekel, 1921 (Ginter et al., 2010). The teeth from the Canning Basin share the pentacuspid crown and strong divergence of the lateral cusps seen in the smaller tooth forms of C. wildungensis (Ginter et al., 2010, figure 66F). The basal features are also comparable, with an elongated lenticular base extending beyond the crown foot as well as possessing the mesio-distally elongated lingual button. Despite these similarities, the cusps on the Canning Basin teeth appear shorter and more robust than those seen in teeth attributed to $C$. wildungensis, including the holotype (Ginter et al., 2010, figure 66). Similar teeth with shorter cusps are evident in a tooth from the Famennian of north-western Iran (Hampe, 2000, plate 2.1-4). Whether these Carboniferous forms belong to $C$. wildungensis is difficult to determine given the limited number of teeth recovered.

\section{Cladodontomorphi indet. sp.}

Figure 5.1-5

Material. One tooth from sample 198404, Laurel Formation, Laurel Downs, Tournaisian.

Description. Asymmetrical tooth comprising five cusps with a large laterally inclined medial cusp and a pair of diverging lateral cusps approximately twice the size of the intermediate cusplets (Figure 5.1). There are fine ridges on the cusp faces with bifurcating ridges on the basal margins of the lateral cusps (Figure 5.1-3). The labial face of the crown is concave at the base with a row of small pores along the base-crown limit. The lingual extension of the base is short and almost trapezoid in outline, extending furthest between the mesial margins of the lateral cusps (Figure 5.4-5). There is a slight lateral extension of the base where it forms a laterally directed point (Figure 5.4). The lingual torus hosts a highly elongate ridge, which extends between the inner margins of lateral cusps and bears six large pore openings along the lingual face. The oro-lingual ridge is thickened at its termination point on one distal end and gradually reduces its size at the other (Figure 5.5) The basolabial shelf is thickest between the accessory cusps, becoming less distinct at one distal margin as opposed to thickening at the other end (Figure 5.3-4). The underside of the tooth bears a shallow depression under the lingual torus that deepens below the main cusp (Figure 5.4).

Remarks. This tooth bears a few features associated with the genus Cladodus. These include a central cusp, which is short and triangular in form, as well as an elongate baso-labial shelf and long oro-lingual ridge. The tooth resembles Cladodus marginatus Agassiz, 1843 (figured in Duffin and Ginter, 2006, figure $3 A-G$ ) with its broad, robust based central cusp directed distally to one side. In addition, the central cusp is biconvex apart from the baso-labial portion where a shallow depression develops. In contrast to $C$. marginatus, the tooth here bears much finer ridges that cover the entirety of each cusp. In C. marginatus the ridges terminate approximately halfway up the cusp from the crownbase interface, with the majority of the upper central cusp surface remaining smooth.

\section{Ctenacanthiform gen. et sp. indet. 1 Figure 5.6-11}

Material. Three teeth from sample 198404, one tooth from sample 198480, four teeth from sample TS-1, Laurel Formation, Laurel Downs, Tournaisian.

Description. The tooth crown comprises a bulbous central cusp flanked by a pair of intermediate cusplets and a pair of lateral cusps diverging distally from the crown centre (Figure 5.6-8). The intermediate cusplets erupt from a more labial position on the crown (Figure 5.9-11) and are strongly fused mesially and distally with the neighbouring cusps. Both cusp faces bear ridges, rarely bifurcating at the base. The base forms a lenticular outline, extending lingually and, in some specimens, mesio-distally beyond the crown base (Figure 5.6). The lingual face of the base forms a steep angle between the lingual margin and the crown-base interface. In some specimens the basal height along the lingual face exceeds that of the crown. 


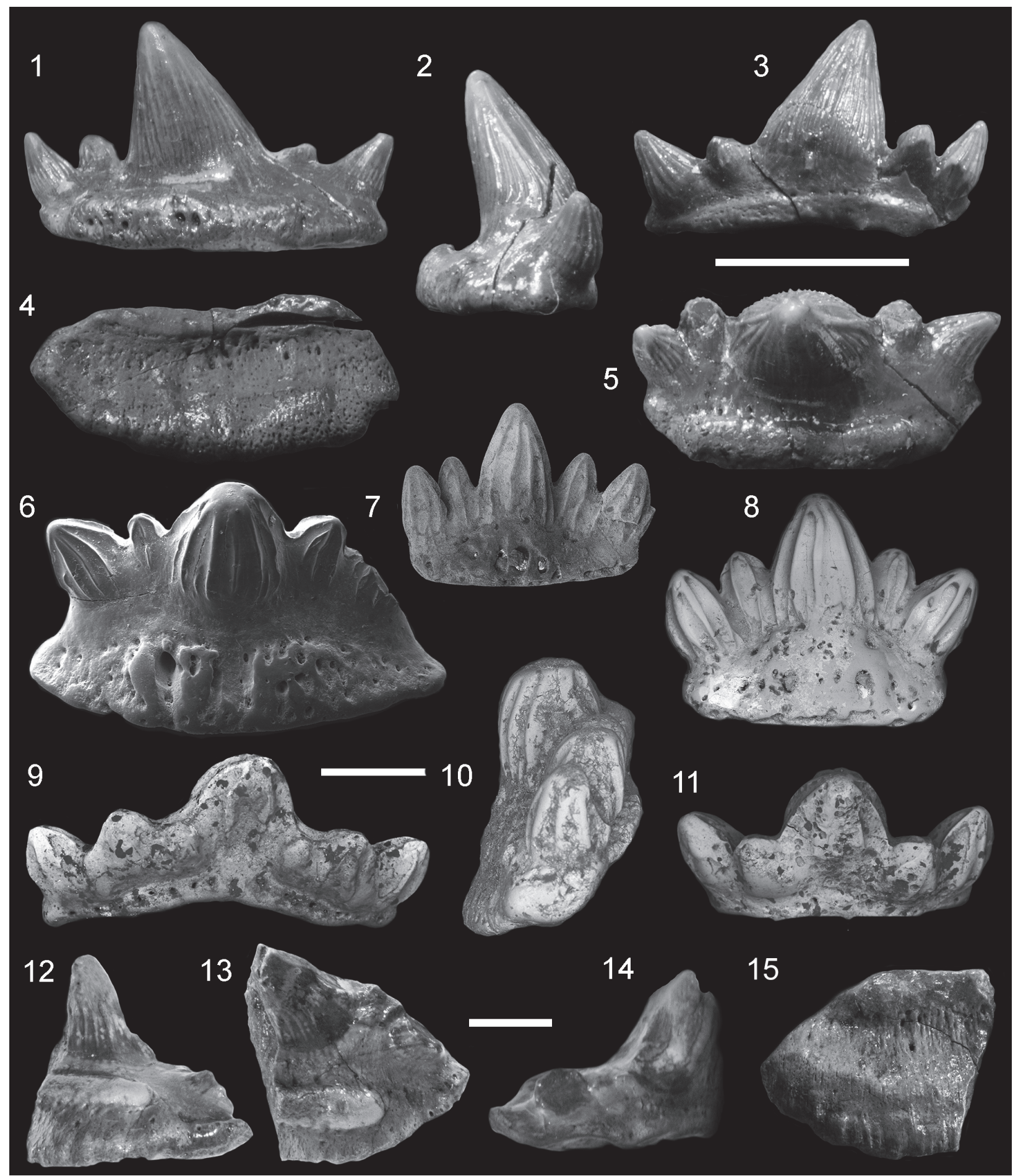

FIGURE 5. Ctenacanthiform teeth from the Lower Carboniferous Laurel Formation, Laurel Downs, Lennard Shelf, Canning Basin, Western Australia. 1-5, Cladodontomorphi indet. sp., WAM 15.6.5, sample 198404, in lingual (1), lateral (2), labial (3), basal (4) and occlusal (5) views; 6-11, Ctenacanthiform gen. et sp. indet. 1, WAM 15.6.24, sample 198404, in lingual view (6), WAM 15.6.36, sample TS-1, in lingual view (7), WAM 15.6.35, sample TS-1, in lingual view (8), WAM 15.6.37, sample TS-1, in labial (9) and lateral (10) views, and WAM 15.6.35, sample TS-1, in labial view (11); 12-15, Ctenacanthiform gen. et sp. indet 2, WAM 15.6.3.8, in lingual (12), occlusal (13), labial (14) and basal (15) views. Scale bar length: 1-5, $10 \mathrm{~mm}$; 6-11, $0.5 \mathrm{~mm} ; 12-15,5 \mathrm{~mm}$. 
An oro-lingual ridge is often poorly developed; however, a series of canals can be found on some specimens, running from the lingual edge of the oro-lingual ridge to almost the crown base interface (Figure 5.6). A row of foramina along an elongate baso-labial shelf extend between the far lateral cusps (Figure 5.9).

Remarks. The tooth crowns are quite distinct in comparison to other cladodont type teeth in that the cusps are highly fused, up to two-thirds of the intermediate cusps with the lateral and central cusps (Figure 5.9, 5.11). Low profiled and similarly fused teeth belonging to Tamiobatis vetustus Eastman, 1897 were recovered from the Cleveland Shale of Ohio, USA (Williams, 1998, figure 5E-F). Williams (1998) suggested these teeth represent the posterior teeth of the shark thereby indicating an unusual degree of heterodonty in this group of sharks. Whether this explains the unusually compact nature of the teeth described here is unclear. The differences in mesio-distal elongation, suggests these teeth occupy a range of positions in the jaw rather than just representing the posterior teeth of one species. The small sample size makes it difficult to correlate any impacts of ontogeny on tooth form. However, a comparison between the smallest tooth (Figure 5.7) and the largest tooth (Figure 5.6), suggests the highly compacted nature of the cusps is not a feature of either juvenile or adult teeth but is a unique character for this species.

Ctenacanthiform fam. gen. et sp. indet. 2 Figure 5.12-15

Material. 1 partial tooth from sample TS-1, Laurel Formation, Laurel Downs, Tournaisian.

Description. Only a small distal portion of the central cusp and part of the lingual torus are preserved (Figure 5.12-15). The remnant of a large central cusp as well as the basal outline of a lateral cusp and intermediate cusplet can be detected. The baso-lingual face of the lateral cusp is approximately twice the size of the basal outline of the intermediate cusplet (Figure 5.13). Approximately one-third of the distal side of the central cusp is preserved. The basal part of the central cusp shows a slight convexity of the lingual face, whereas the labial face is flattened. In unabraded areas, the lingual faces of both the central and lateral cusps bear thin vertical striae (Figure 5.12-13). The distal limit of a baso-labial depression can be seen on the central cusp (Figure 5.14). A row of faint foramina runs along the crown-base interface on the labial side of the tooth. The base extends lingually with the preserved part of the crenulated lingual rim showing a gentle curvature (Figure 5.15). Part of a well-defined, elongate oro-lingual button is positioned midway between the crown base and the lingual margin and extends from the broken face of the tooth to the base of the intermediate cusp. A thickened but incomplete baso-labial shelf lies between the broken edge of the distal margin of the central cusp and the mesial margin of the lateral cusp.

Remarks. The small fragment of the tooth does not preserve many of the diagnostic features in their entirety and makes any in depth comparisons difficult. The preserved end of the baso-labial shelf extends to the basal part of the lateral cusp and appears slightly thickened. The preserved section of the oro-lingual ridge is straight and extends to the inner edge of the lateral cusp base. These features indicate affinities to the Ctenacanthiforms. The oro-lingual button on many Cladodus terrelli Newberry, 1889 teeth is similar in shape and positioned centrally on the lingual torus, extending between the inner margins of the lateral cusps. The thin nature of the baso-lingual margin and vertical ridges are similar to those on the teeth of Cladodus terrelli.

Cohort EUSELACHII Hay, 1902

Superfamily PROTACRODONTOIDEA Zangerl, 1981

Family PROTACRODONTIDAE Cappetta, Duffin and Zidek, 1993

Genus PROTACRODUS Jaekel, 1925

Type Species. Protacrodus vestustus Jaekel, 1921

Protacrodus aequalis Ivanov, 1996

Figure 6.1

v. 1982 Protacrodus sp. 'C'; Turner, pp. 125-126, fig. 7.

v. 1994 Protacrodus sp. C; Ivanov and Lukševičs, pp. 25-26, fig. i, j.

v. 1996 Protacrodus aequalis sp. nov.; Ivanov, p. 423, fig. 6A-G.

v. 1999 Protacrodus aequalis Ivanov; Ginter and Turner, p. 113, fig. 7A-C.

v. 2000 Protacrodus aequalis Ivanov; Ginter and Ivanov, p. 339, pl. 21.

v. 2005 Protacrodus sp. 3; Derycke-Khatir, pp. 6465 , pl. VIII, fig. 8.

v. 2010 Protacrodus aequalis Ivanov; Ginter, Hampe and Duffin, p. 87, fig. 80D, E.

v. 2011 Protacrodus aequalis Ivanov; Ivanov and Lucas, p. 58, fig. 6A-L. 


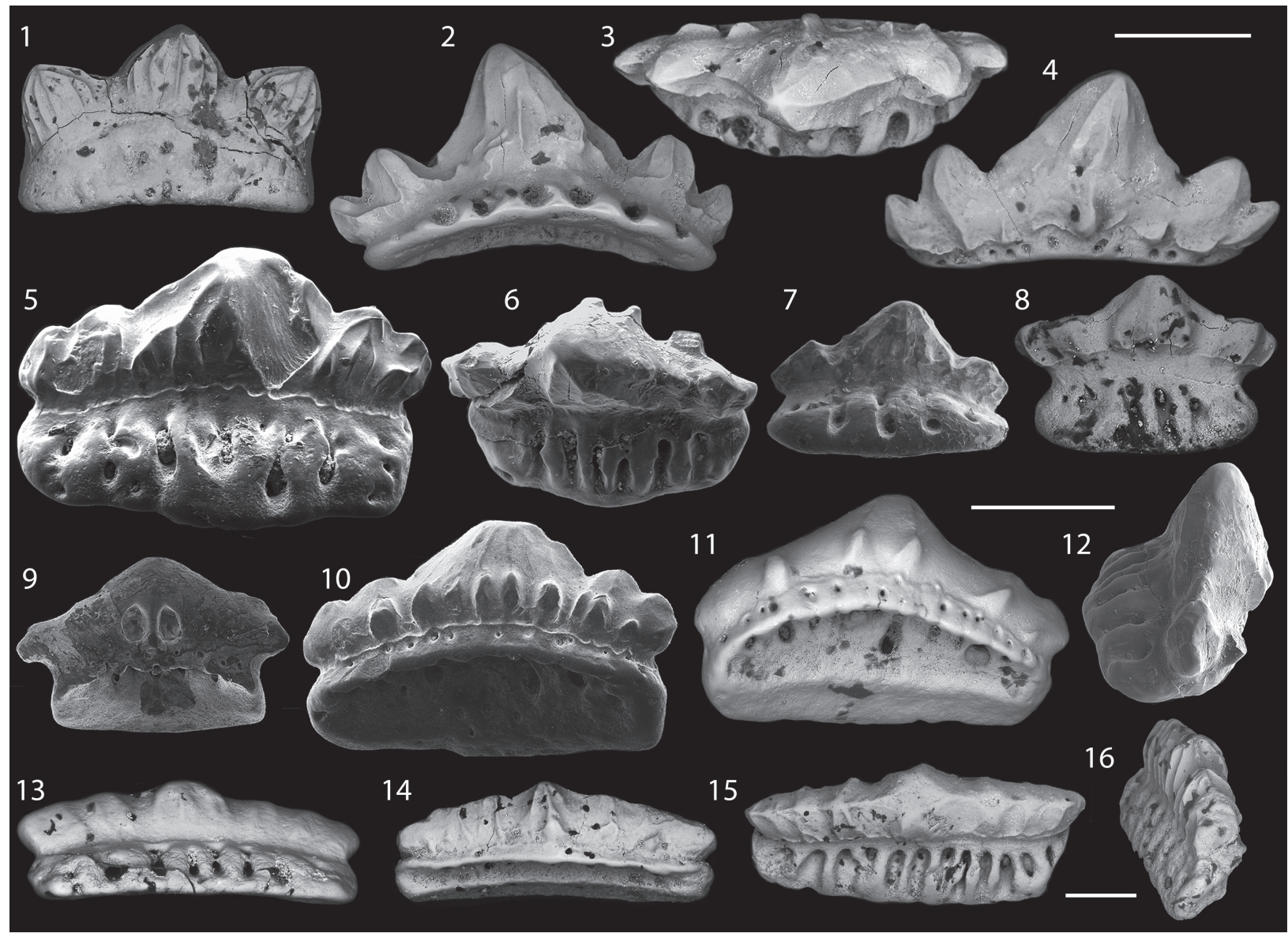

FIGURE 6. Protacrodont teeth from Lower Carboniferous Laurel Formation, Laurel Downs, Lennard Shelf, Canning Basin, Western Australia. 1, Protacrodus aequalis, WAM 15.6.43, sample TS-1, in lingual view (1); 2-4, Protacrodus sp. 1, WAM 15.6.45, sample TS-1, in lingual (2), occlusal (3) and labial (4) views; 5-12, Deihim mansureae, WAM 15.6.17, in lingual view (5), WAM 15.6.18, sample 198408, in occlusal view (6), WAM 15.6.46, sample TS-1, in lingual view (7), WAM 15.6.48, sample TS-1, in lingual view (8), WAM 15.6.19, sample 198404, in labio-basal view (9), WAM 15.6.17, sample 198404, in labial view (10), WAM 15.6.49, sample TS-1, in labio-basal view (11), and WAM 15.6.18, sample 198404, in lateral view (12); 13-16, Dalmehodus cf. turnerae, WAM 15.6.30, sample LG-1, in lingual (13) and labial (14) views, WAM 15.6.44, sample TS-1, in occlusal (15) and lateral (16) views. Scale bar length: 1-4, 0.5 mm; 5$12,1 \mathrm{~mm} ; 13-16,0.25 \mathrm{~mm}$.

Material. One tooth from sample TS-1, Laurel Formation, Laurel Downs, Tournaisian.

Description. Tooth with a tricuspid crown, comprising a central cusp and two lateral cusps diverging at 45 degrees from the base (Figure 6.1). The cusps are compressed labio-lingually, and short and wide in lingual view. The central cusp is slightly larger than the lateral cusps, which are fused at the base to the central cusp. The cusps are all ornamented with strong cristae, which converge at the cusp apices (Figure 6.1). The base is bulbous with a rounded lingual extension covered by small pores. A row of small foramina occur above a slightly arched crown-base interface on the labial side.
Remarks. The symmetrical nature of the tooth is unusual in comparison to the majority of teeth attributed to this species. Typically, the crown of $P$. aequalis comprises cusps that are inclined to a distal side. A similar symmetrical tooth, is figured in Ivanov (1996, figure 6F) but shows a pair of lateral cusps with less distal divergence than the tooth from the Canning Basin. The symmetrical nature of this tooth suggests placement within symphyseal region of the mandible and possibly explains the low numbers recovered.

Distribution and stratigraphic range. Recorded from the early Famennian in Arctic Canada (Ginter and Turner, 1999), middle Famennian of Latvia (Ivanov and Lukševičs, 1994) and the late Famennian in New Mexico, USA (Ivanov and Lucas, 
2011). Within the South Urals, Russia, this species is known from the latest Famennian to early Tournaisian (sulcata CZ; Ivanov, 1996). In Australia, P. aequalis is known from the Famennian in Queensland (Turner, 1982) and the Tournaisian in the Canning Basin, Western Australia. This species has also been recorded from the Tournaisian in Belgium (Derycke-Khatir, 2005).

\section{Protacrodus sp. 1 \\ Figure 6.2-4}

v. 2011 Protacrodus sp.; Habibi and Ginter, p. 39, pl. $2 b-e$.

Material. One tooth from sample TS-1, Laurel Formation, Laurel Downs, Tournaisian.

Description. Crown is thin labio-lingually with five cusps; a large triangular central cusp and two pairs of lateral cusps diminishing in size distally (Figure 6.2). The central cusp is three times the size of the first lateral cusps and makes up approximately half the size of the crown (Figure 6.2, 6.4). The second pair of lateral cusps is approximately half the size of the first pair and diverge at approximately 45 degrees from the centre of the crown. Coarse cristae are present on both faces of the crown. On the labial face, the cristae thicken around the crown base interface to the extent they resemble small cusplets (Figure 6.3-4). In outline, the base is straight along the labial face with a gently curved lingual margin (Figure 6.3). The lingual face of the base is perforated by a row of large canals that decrease in size toward the distal margins. The labial face of the base is thin and gently arched with a single row of small pores (Figure 6.4).

Remarks. The tooth superficially resembles Deihim mansureae Ginter, Hairapetian and Klug, 2002 but differs in that the central cusp in Protacrodus $\mathrm{sp}$. is more pronounced with the lateral cusps not as highly fused as they are in $D$. mansureae. In addition, the tooth described here bears a shorter lingual extension of the base and lacks the characteristic cusplets. The crown and basal morphologies bear a very strong resemblance to Protacrodus sp. teeth figured in Habibi and Ginter (2011, plate 2, figure b-e). The basal canals in the specimen from the Canning Basin are focused into a single row. The cristae around the crown-base interface on the labial side are also far coarser. These differences, however, do not appear significant enough to separate these species and so we determine this tooth belongs to the same species as Protacrodus sp. from the Central Alborz Mountains, Iran (Habibi and Ginter, 2011).
Genus DEIHIM Ginter, Hairapetian and Klug, 2002

Deihim mansureae Ginter, Hairapetian and Klug, 2002

Figure 6.5-12

v. 2000 ?Protacrodus sp.; Long and Hairapetian, pp. 217-218, fig. 40.

v. 2000 Protacrodus sp. cf. "P. aequalis" sensu Ginter and Turner; Yazdi and Turner, p. 226, figs. 3.4-7, 4.4 .

v. 2002 Deihim mansureae gen. et sp. nov.; Ginter, Hairapetian and Klug, pp. 191-193, textfig. 10; pl. 1, fig. r; pl. 2, fig. k; pl. 4, figs. fg, j-m; pl. 5, figs a-m.

v. 2005 Polyacrodontidae incertae sedis; DeryckeKhatir, p. 76, pl. VII, figs. 7-10.

v. 2005 Bobbodus sp.; Derycke-Khatir, pp. 95-96, pl. XII, figs. 1-2.

v. 2009 Deihim mansureae Ginter, Hairapetian and Klug; Hairapetian and Ginter, pp. 176- 179, figs. $2 \mathrm{D}, 4 \mathrm{H}$.

v. 2010 Deihim mansureae Ginter, Hairapetian and Klug; Hairapetian and Ginter, p. 362, fig. 3A.

v. 2010 Deihim mansureae Ginter, Hairapetian and Klug; Ginter, Hampe and Duffin, p. 88, fig. 81A-J.

v. 2011 Deihim mansureae Ginter, Hairapetian and Klug; Ginter, Hairapetian and Grigoryan, pp. 166-169, figs. 8A-E, 11C.

v. 2011 Deihim mansureae Ginter, Hairapetian and Klug; Ivanov and Lucas, p. 60, fig. 8.

v. 2013 Deihim mansureae Ginter, Hairapetian and Klug; Habibi, Yazdi, Zarepoor and Shirazi, p. 30, fig. 4.

v. 2015 Deihim mansureae Ginter, Hairapetian and Klug; Roelofs, Playton, Barham and Trinajstic, p. 88, text-fig. 6.

Material. One tooth from sample $\mathrm{OH}-4$, Gumhole Formation, Oscar Hill, Famennian; 12 teeth from sample 198404, two teeth from samples 198480 , six teeth from sample TS-1, Laurel Formation, Laurel Downs, Tournaisian.

Description. Two different tooth morphotypes can be distinguished. The first tooth type is pentacuspid, comprising a large medial cusp approximately twice as high as the two pairs of highly fused lateral cusps (Figure 6.5-6). The crown is ornamented on both faces with coarse cristae. Four to nine cusplets are present on the labial side (Figure 6.1012). A shallow groove marks the crown-base interface on the lingual face of the tooth. The base 
extends lingually, furthest at the centre of the lingual margin (Figure 6.6). A few large canals perforate the occlusal-lingual face of the base from the lingual margin to the crown base. A row of small pores are present along the labial face of the base, immediately below the crown (Figure 6.10-11).

The second tooth type is smaller, possessing a large triangular central cusp with one to two pairs of smaller, laterally diverging cusps (Figure 6.7-9). Cristae are most prominent on the lingual face of the crown. The labial face of the crown typically bears four cusplets with one tooth (WAM 15.6.19, Figure 6.9) possessing a single pair of prominent ovoid labial cusplets. A row of small pores within a shallow trough, mark the crown-base interface on the labial face. The crown-base interface forms a low arch. The base is semi-circular in outline extending distally and lingually beyond the crown base (Figure 6.7-8).

Remarks. The teeth bear the diagnostic characters of $D$. mansureae, including the large central cusp, diverging lateral cusps and a row of cusplets along the labial face of the crown. However, these teeth differ from the original morphotypes outlined by Ginter et al. (2002) in regards to cusp number and the variation in size between the central and lateral cusps. The first tooth type recovered from the Canning Basin consists of crowns resembling those of Morphotype 1 (sensu Ginter et al., 2002); however, the mesio-distally extended base and low profile of the central cusp is more similar to Morphotoype 2. Examples of Morphotype 3 are lacking from the teeth collected here. The few Morphotype 4 teeth that were recovered (Figure 6.7-8) comprise a central cusp that is significantly lower in profile than other examples of this morphotype figured in Ginter et al. (2002, plate 5D-F). The teeth from the Canning Basin do not fully conform to any of the morphotypes originally described (Ginter et al., 2002) and suggests these teeth may belong to a different species than the older Famennian forms found in Iran.

\section{Genus DALMEHODUS Long and Hairapetian, 2000 \\ Dalmehodus cf. turnerae \\ Figure 6.13-16}

Material. Seven teeth from sample LG-1, 11 teeth from sample 198404 and two teeth from TS-1, Laurel Formation, Laurel Downs, Tournaisian.

Description. Mesio-distally elongated teeth with slightly arched crowns comprising a low central cusp and between two and four almost completely fused lateral cusps that decrease in size distally (Figure 6.13-14). The central cusp varies from equal in size to slightly larger than the first pair of lateral cusps. Cusps are ornamented with faint to strong cristae (Figure 6.14, 6.16). The base is roughly rectangular, extending lingually, and barely developed beyond the crown distally (Figure 6.1516). A row of large furrows are present along the lingual face of the base and extend from the lingual margin of the base to the crown base interface. The labial face of the base is small with a few small pores. The underside of the base is concave below the crown and flattened on the underside of the baso-lingual extension.

Remarks. The teeth resemble those previously attributed to Dalmehodus turnerae Long and Hairapetian, 2000, in they possess a low, mesio-distally elongate crown covered in coarse cristae and a lingually short base with a row of rather large foramina. A key feature distinguishing teeth of $D$. turnerae from other protacrodonts is the lack of a discernible size difference between the central and lateral cusps. Typically, the teeth from the Canning Basin bear a central cusp slightly larger than the lateral cusps. Teeth with highly fused cusps figured in Ginter et al. (2011, text-figure 10H) and those in Hairapetian and Ginter (2009, text-figure 4B) most closely resemble the teeth from the Canning Basin and these were attributed to $D$. turnerae. Despite the large number of teeth from the Tournaisian deposits, the variation in morphology is limited. Teeth resembling the holotype (Long and Hairapetian, 2000, figure 6f) and other specimens (Hairapetian and Ginter, 2009, text-figure 9A-B) with less fusing of the cusps have not been found in samples from the Canning Basin. It may be that the teeth found here, as well as similar forms in Iran (Hairapetian and Ginter, 2009) and Armenia (Ginter et al., 2011), represent different protacrodont species.

\section{Protacrodontidae gen. et $\mathrm{sp}$. indet.}

Figure 7.1-2

Material. A partial tooth from sample $\mathrm{OH}-4$, Gumhole Formation, Oscar Hill, Famennian.

Description. The preserved part of the crown comprises a large triangular cusp and four smaller lateral cusps (Figure 7.1-2) all ornamented with strong linear cristae. The first and second lateral cusps are almost equal in size with the third and fourth cusps diminishing in size distally. On the lingual side of the crown a row of four small rounded cusplets occur between the central and second lateral cusp (Figure 7.1). There is a row of larger, more irregularly shaped cusplets on the entire preserved labial side of the crown (Figure 7.2). A distinct crown-base interface is lacking on the labial 


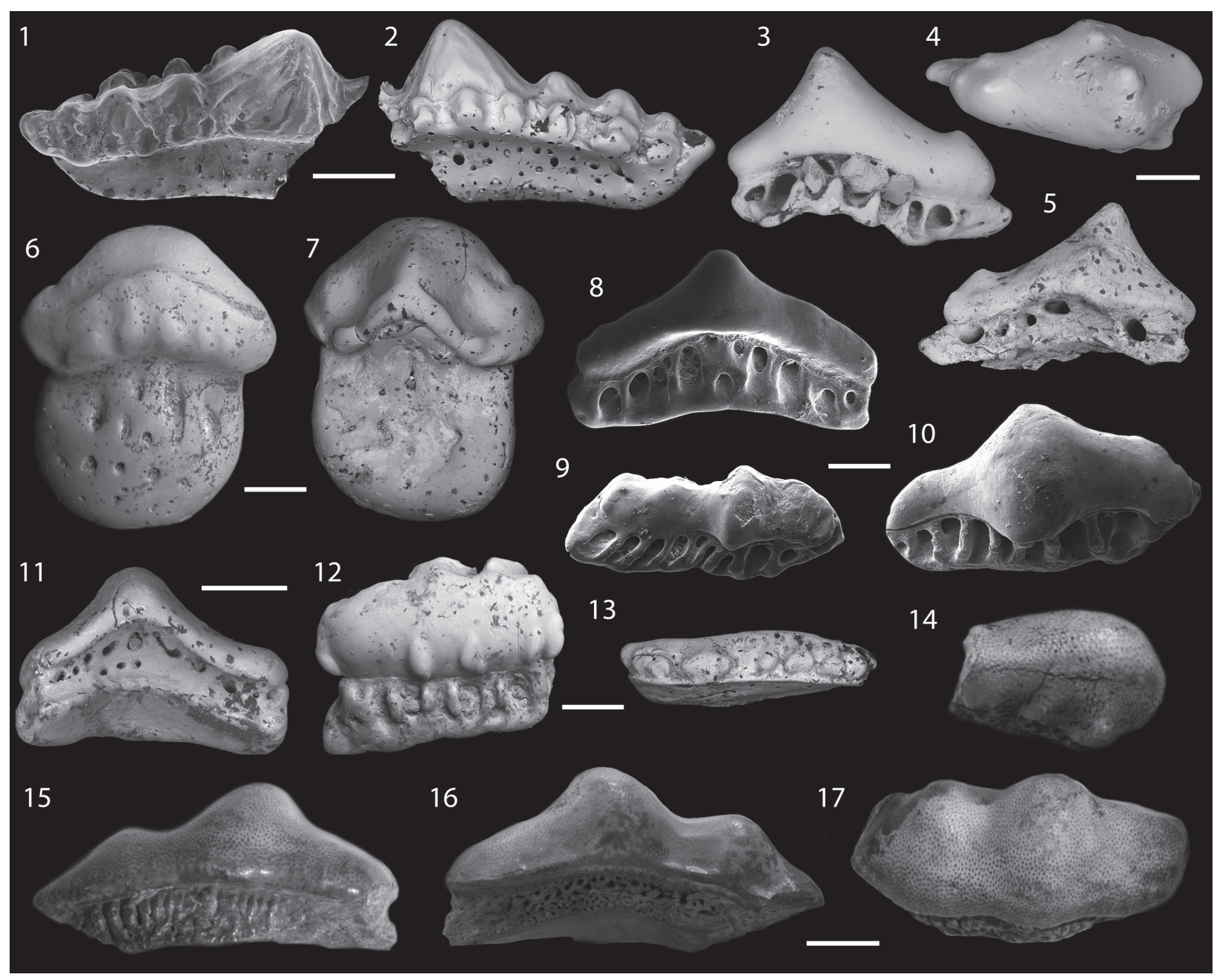

FIGURE 7. Shark teeth from the Upper Devonian Gumhole Formation, Oscar Hill and Lower Carboniferous Laurel Formation, Laurel Downs, Lennard Shelf, Canning Basin, Western Australia. 1-2, Protacrodontidae gen. et sp. indet., WAM 15.6.29, sample OH-4, in lingual (1) and labial (2) views; 3-5, Lissodus sp., WAM 15.6.42, sample TS-1, in lingual (3), occlusal (4) and labial (5) views; 6-7, Hybodontoidea gen. et sp. indet., WAM 15.6.41, sample TS-1, in lingual (6) and labial (7) views; 8-11, Euselachii gen. et sp. indet.1, WAM 15.6.21, sample 198404, in lingual view (8), WAM 15.6.20, sample 198404, in occlusal view (9), WAM 15.6.27, sample 198404, in occluso-lingual view (10), and WAM 15.6.39, sample TS-1 in labial view (11); 12-13, Euselachii gen. et sp. indet. 2, WAM 15.6.40, sample TS-1, in occluso-lingual view (12) and WAM 15.6.22, sample TS-1, in labial view (13); 14-17, Holocephali gen. et sp. indet. 1, WAM 15.6.4, sample 198404, in occlusal view (14), and WAM 15.6.3, sample 198404, in lingual (15), labial (16) and occlusal (17) views. Scale bar length: 1-2, $0.5 \mathrm{~mm} ; 3-5,0.4 \mathrm{~mm} ; \mathbf{6 - 7}, 0.75 \mathrm{~mm}$; 8-10, 0.3 mm; 11, 1 mm; 12-13, 0.6 $\mathrm{mm} ; 14-17,5 \mathrm{~mm}$.

side of the tooth. The base is mesio-distally shorter than the crown but extends lingually and is perforated by small pores.

Order HYBODONTIFORMES Cappetta, Duffin and Zidek, 1993

Superfamily HYBODONTOIDEA Owen, 1846 Family LONCHIDIIDAE Herman, 1977 Genus LISSODUS Brough, 1935

Type Species. Lissodus africanus Broom, 1909

\section{Lissodus $\mathrm{sp}$.}

Figure 7.3-5

Material. One tooth from sample TS-1, Laurel Formation, Laurel Downs, Tournaisian.

Description. Asymmetrical tooth with an arched crown consisting of a high central cusp and a single, almost completely fused lateral cusp (Figure 7.3). A broad, rounded labial peg extends labially from the centre of the crown base (Figure 7.4). The crown is completely smooth, lacking any form of 
ornament. The base is labio-lingually narrow and extends lingually and distally beyond the crown base on one side. The crown overhangs a concave trough along the labial side of the base. The base has a row of large canal openings present on the lingual face with corresponding openings on the labial side (Figure 7.5).

Remarks. This tooth possesses characters typical of the genus Lissodus, including a single central cusp, labial peg and lingually extended base, perforated by large vascular canals. In comparison to other Early Carboniferous Lissodus teeth figured in Duncan (2004), the crown is much higher, forming a more pointed apex. The basal features are also distinct, with a row of very large canals on the lingual face of the base and large canal openings along the baso-labial side. The aforementioned features also distinguish the tooth from other Early Carboniferous Lissodus teeth listed in Fischer (2008). A reconstruction of the dentition of Lissodus nodosus Seilacher, 1943 (Duffin, 1985) and an interpretative reconstruction of Lissodus sp. by Duncan (2004) indicate a degree of variation among the tooth morphotypes. It is possible that the unusual features of the tooth described here may be a product of its position in the jaw.

The labial overhang of the main cusp and large canal openings on the base, present in the tooth here, are similar to the teeth of another Hybodont shark, Cassisodus margaritae Ginter and Sun, 2007 from Muhua, South China. The tooth however lacks a main diagnostic character of the genus Cassisodus, which is the presence of lingual and labial cusplets present on both faces of the crown. The possibility of wear or abrasion contributing to the lack of cusplets is unlikely as the crown retains a shiny enameloid surface.

Hybodontoidea gen. et sp. indet. Figure 7.6-7

Material. One tooth from sample TS-1, Laurel Formation, Laurel Downs, Tournaisian.

Description. A well-preserved tooth with a large vertical bulbous crown that overhangs the lingual and distal faces of the base. The lower half of the crown, on the lingual face, is raised and bears a row of low profiled ovoid cusplets running mesiodistally (Figure 7.6). A pair of large pits is present on the distal sides of the distinct labial peg (Figure 7.7). The crown base interface on the labial side is highly arched with a thickened margin. The lingual margin of the base is semicircular and approximately one and a half times as deep as the crown height. The lingual face is slightly convex and perforated by three horizontally aligned rows of pores
(Figure 7.6). Small pores are present in and around the concave labial side of the base.

Remarks. This tooth is unusual with the elongate base directed under the crown. The labial peg and fused crown is similar to some Hybodonts such as Lissodus. However, the base lacks the large vascular foramina typical of that genus. In overall morphology, the tooth bears a resemblance with a hybodont tooth figured in Ginter and Sun (2007, figure $6 \mathrm{~A}_{1-3}$ ) with the large labial peg, pyramidal crown and deep base orientated directly under the crown.

Euselachii gen. et sp. indet. 1

Figure 7.8-11

Material. Six teeth from 198404, two teeth from 198480, nine teeth from TS-1, Laurel Formation, Laurel Downs, Tournaisian.

Description. Tooth crowns with two morphologies but both with a similar euselachian basal form. The crown and base are separated by a small but distinct lingual groove on the lingual face of the tooth. The base extends lingually and ranges from symmetrical (Figure 7.8) to asymmetrical in outline (Figure 7.9). A row of large canals extend from baso-lingual margin to the crown base. On the labial face of the tooth, the margin between the crown and base is often marked by a significant concavity (Figure 7.11). A large pore network covers the concave underside of the crown whereas the underside of the baso-lingual extension is smooth.

Crown Morphotype 1 is symmetrical in form (Figure 7.8) with a high, prominent medial point and steeply tapering margins. The crown is smooth with only faint, rounded cusp type projections along the occlusal surface of some teeth (Figure 7.8). The crown margins are rounded and do not overhang the base.

Crown Morphotype 2 is asymmetrical with a large bulbous central cusp overhanging the lingual margin (Figure 7.10), and two to three smaller lateral cusps. Tooth crowns with three cusps, possess a slightly flattened and distally tapering lateral cusp on one side (Figure 7.10-11). The opposite lateral cusp forms a small dome, approximately half the size of the central cusp, and in some specimens overhangs the labial face of the crown. In one specimen (WAM 15.6.20, Figure 7.9), the tooth comprises four cusps; a central cusp with a single flattened lateral cusp on one side and two smaller rounded cusps, decreasing in size distally, on the other. The cusps all possess a slight distally directed orientation with the largest cusp overhanging both the lingual and labial margins. 
Remarks. Both morphotypes are here considered to represent a single taxon based on the high degree of heterodonty amongst other sharks with clutching-crushing dentitions (e.g., Heterodontus). Some of the teeth (Figure 7.10-11) superficially resemble the teeth attributed to Holocephali gen. et $\mathrm{sp}$. indet. with their low profile bulbous cusps and lingually extending base perforated by a series of elongate canals. The crowns of the Holocephali gen. et sp. indet. teeth, however, differ from Euselachii gen. et $\mathrm{sp}$. indet. 1 due to the small pores covering the crown and a central cusp that overhangs the labial face of the crown-base interface rather than overhanging the lingual margin.

Euselachii gen. et sp. indet. 2

Figure 7.12-13

Material. Seven teeth from sample 198404, nine partial teeth from sample TS-1, Laurel Formation, Laurel Downs, Tournaisian.

Description. Asymmetrical teeth that are highly flattened along the occlusal surface. The crown is almost rectangular in outline with a low convex occlusal surface (Figure 7.12-13). The surface of the tooth is covered by small rounded areas of discolouration, which are sometimes associated with small pits that do not appear to project into the dentine layer. There are two rows of cusplets: large irregularly shaped cusplets along the labial face (Figure 7.13) and smaller rounded cusplets along the lingual face (Figure 7.12). The occlusal facing base extends lingually and is perforated by a series of elongate canals. The baso-labial side of the crown is thin and lacks a clear crown-base interface.

Remarks. These teeth possess a range of characters including the wide canal openings similar to Euselachii gen. et sp. indet. 1; as well as different cusplet types on the labial and lingual faces of the crown that appear similar to Protacrodontidae gen. et. sp. The mesio-distal elongation of the teeth in conjunction with lingual and labial cusplets is diagnostic of lateral teeth attributed to the genus Cassisodus. In addition, the crown positions on the teeth of Cassisodus margaritae and Euselachii gen. et $\mathrm{sp}$. indet. 2 are more labial, creating a slightly labio-lingual elongation. However, the crown of Cassisodus is far more pronounced with accessory labial and lingual cusplets of equal size. Due to the rarity of these teeth and the asymmetrical form, it is possible these teeth are part of a more complex dentition of another species.

\section{Subclass EUCHONDROCEPHALI Lund and Grogan, 1997}

Superorder HOLOCEPHALI Bonaparte, 1831 Holocephali gen. et sp. indet.

Figure 7.14-17

Material. 12 teeth from 198404, two teeth from 198480, seven teeth from TS-1, Laurel Formation, Laurel Downs, Tournaisian.

Description. Large teeth up to $21 \mathrm{~mm}$ across the crown, mesio-distally. The crown is asymmetrical and covered in a series of minute pores (Figure 7.14-15). The centre of the crown is elevated, forming a large bulbous projection with a rounded, labially directed apex that overhangs the base on the labial margin (Figure 7.16-17). On one side of the main projection is a smaller one, approximately half the size and also directed labially. The other distal end of the crown is flattened with no discernible elevation. A row of well-developed cusplets is present on the baso-labial side of one incomplete tooth crown (WAM 15.6.14, Figure 7.14). The boundary between the crown and base on the lingual side of the tooth is marked by a shallow groove. The base has a short lingual extension with some teeth preserving thin distal margins extending beyond the crown. A row of tightly packed canals, extending from the lingual margin to the crown base, occupy the lingual face of the base (Figure 7.15). The labial face of the base is thin and borders a shallow trough perforated by small pores. The underside of the baso-linguinal extension and majority of the crown is gently convex and smooth, devoid of foramina.

Remarks. Teeth conforming to this morphology were first documented in the Canning Basin by Thomas $(1957,1959)$ who published photographs of "Bradyodont" teeth from the Laurel Formation. These teeth were later redescribed by Turner (1982) who tentatively attributed them to the genus Helodus. The teeth described here and the ones previously recovered from the Laurel Formation, both share crowns perforated by tiny pores as well as a base with small, elongate canals. In addition, the labial side of the base in these teeth are also highly vascularised. The teeth described here likely represent the same species previously recovered from the Laurel Formation with differences in crown and base shape that can be attributed to the high degree of heterodonty found in "bradyodont" sharks.

There are few features present in these isolated teeth that can be used to confidently identify them to a species level. Similar teeth have been recovered in Muhua, China, and attributed to Helodus conicus Newberry and Worthen, 1866, however no descriptive comparison to the original teeth 
of this species was given (Ginter and Sun, 2007). The mesio-distally elongate teeth from the Canning Basin share a general morphology including a high midpoint to the crown with a surface covered in small pores. In contrast, the presence of a more developed bulbous projection on one side of the crown centre, tightly packed pore canals on the lingual face of the base as well as a wider labio-lingual morphology distinguishes these teeth from those of Muhua. Characters such as tubular dentine and a bulbous crown are typical of teeth assigned to the genus Helodus, however these are not genera specific. As the similarities do not appear significant enough to be included under the same genera, we have left the teeth in open nomenclature.

\section{DISCUSSION}

\section{Faunal Assemblages and Biofacies Controls}

A chondrichthyan biofacies model, based on shark teeth, was proposed by Ginter (2000) for upper Famennian assemblages with a pan tropical distribution across south-east Laurussia and northwest Gondwana. Here we compare the shark fauna from the Carboniferous Laurel Formation with the biofacies model to ascertain if it also applies to Carboniferous faunas, especially in light of the end-Famennian vertebrate extinctions and environmental perturbations. The Famennian shark biofacies model consists of three distinct biofacies based on water depth and the percentages of shark teeth recovered (Ginter, 2000, 2001). These include: a Jalodus biofacies, containing more than $25 \%$ Jalodus, interpreted to indicate an open, deep water environment; a Phoebodus biofacies with more than $25 \%$ Thrinacodus tranquillus and Phoebodus, representing a shallower slope to shelf environment; and, a Protacrodus biofacies with more than $25 \%$ protacrodont and orodont teeth, indicating an even shallower marine environment. Previous work on the Late Devonian shark fauna from the Canning Basin has found similarities between the Jalodus biofacies type and the Frasnian shark fauna from the upper to distal slope facies of the Virgin Hills Formation, which largely comprises Phoebodus species (Trinajstic and George, 2009; Roelofs et al., 2015). A Protacrodus biofacies has also been identified in a fossil rich shallow water middle Famennian Bugle Gap limestone, which mainly comprises protacrodonts and the phoebodont Th. tranquillus (Roelofs et al., 2015). However, it was not possible to apply the biofacies model to the latest Famennian Gumhole
Formation in this work due to the low numbers of teeth recovered from the cross stratified ooidal grainstones, a facies type that has been previously recognised as not conducive to preserving vertebrate fossils (Boessenecker et al., 2014).

In contrast the lithofacies of the Laurel Formation comprise well bedded limestones with vertebrate remains recovered mostly from crinoidal grainstones, which are more favourable to the preservation and accumulation of vertebrate fossils (Druce and Radke, 1979). The shark fauna of the Laurel Formation is diverse, consisting of at least 16 species, and is dominated by three main tooth types: crushing or grinding (51\%); phoebodont (represented by Thrinacodus ferox, 24\%); and cladodont (22\%). Ageleodus teeth comprise a small fraction of all teeth recovered $(3 \%)$ and have been previously found in shallow water facies (Downs and Daeschler, 2001; Anderson, 2009). The high percentage of crushing or grinding teeth is comparable to the shallow water Protacrodus biofacies (sensu Ginter, 2000, 2001) in Famennian sections in Utah and Nevada, USA, and the Tafilalt Platform in Morocco (Ginter, 2001) and demonstrates that the Prorocrodus biofacies may be applied to the shallow water environments within the lower Carboniferous. The presence of this biofacies in the Canning Basin indicates comparable taxa, such as Protacrodonts and Helodonts, continued to inhabit equivalent, globally distributed, shallow water environments in the early Carboniferous. Habibi and Ginter (2011) also noted the occurrence of the Protacrodus biofacies in Tournaisian shallow shelf facies at Shahmirzad, central Iran. However, the proportions of Protacrodontidae teeth $(=25 \%)$, as well as Holocephali $(=12 \%)$ and the morphologically similar Euselachii gen. et sp. indet. 1 teeth (= $12 \%$ ), are much higher in the Canning Basin than at Shahmirzad. This distinction may be influenced by localised environmental differences. The Laurel Formation contains a series of very shallow water carbonate facies, similar to those in the Tournaisian at Muhua, China (Ginter and Sun, 2007) and a similar high percentage of crushing Holocephalan type teeth. Drawing conclusions from these two assemblages is difficult; however, it is possible that high numbers of Holocephalan teeth may indicate an even shallow water biofacies. There is also the possibility the high numbers of Euselachii gen. et sp. indet. 1 and Holocephalan teeth are a response to changes in the shell durability of prey species. Kosnik et al. (2011) found a decrease in the shell reinforcement (sensu Kosnik et al., 2011) of brachiopods from the Carboniferous, which may have 

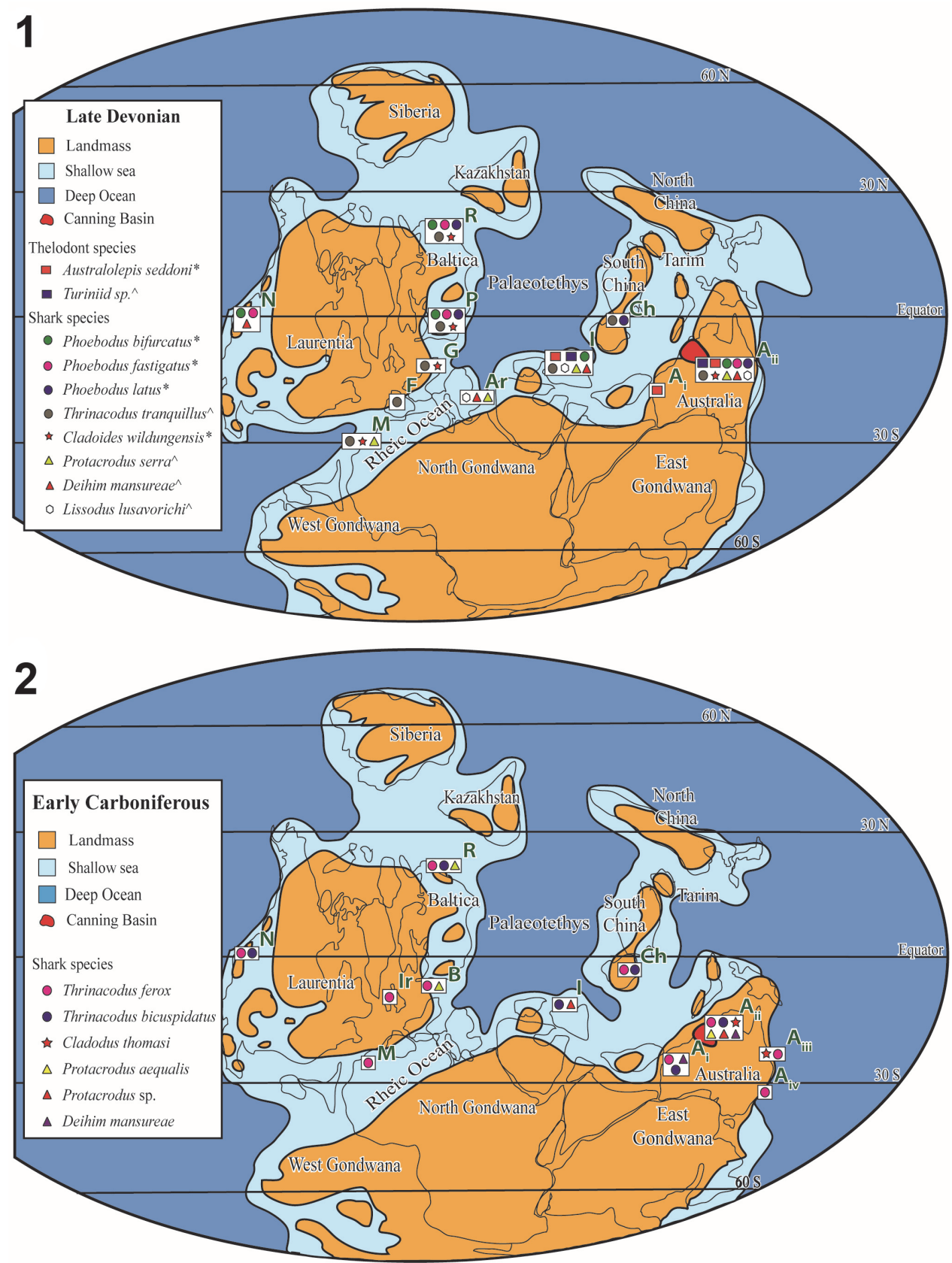

FIGURE 8. Maps depicting common taxa between the Canning Basin and other areas in Gondwana and Laurentia for the Late Devonian (1, Frasnian and Famennian chondrichthyans - * indicating Frasnian age, ^ indicating Famennian age) and Early Carboniferous (2, Tournaisian to Visean) (base map modified from Scotese and McKerrow, 1990; Golonka et al., 1994; Metcalfe, 2011). Abbreviations: A, Khor Virap and Erytch, Armenia; $\mathbf{A}_{\mathbf{i}}$, Carnarvon Basin, Australia; $\mathbf{A}_{\mathbf{i i}}$, Canning Basin, Australia; $\mathbf{A}_{\mathbf{i i i}}$, Burdekin Star, Australia; $\mathbf{A}_{\mathbf{i v}}$, Broken River, Australia; B, Belgium; Ch, Hunan, South China; F, Montagne Noire, France; G, Thuringia, Germany; I, Chahriseh, Dalmeh, Hojedk, Hutk, and Kale-Sardar, Iran; Ir, Kilbride, Ireland: M, Tafilalt, Morocco; N, Nevada, Utah, and New Mexico, North America; P, Holy Cross Mountains, Poland; and R, South Urals, Russia. Sources of information: Armenia (Ginter et al., 2011), Australia (Turner and Dring, 1981; Turner, 1982; Trinajstic, 2001; Trinajstic and George, 2009; Roelofs et al., 2015), Royseux, Belgium (Derycke-Khatir et al., 2005), China (Wang and Turner, 1985; Ginter and Sun 2007), France (Derycke-Khatir et al., 2005), Germany (Ginter, 1999), Iran (Long and Hairapetian, 2000; Ginter et al., 2002; Hairapetian and Ginter, 2010), Ireland (Duncan, 2003), Morocco (Ginter et al., 2002; Derycke et al., 2008), North America (Ginter, 2001; Ivanov and Lucas, 2011), Poland (Ginter, 1990, 1995; Ginter and Ivanov, 2000), Russia (Ginter, 1994; Ginter and Ivanov, 1992, 2000; Ivanov, 1996), and South China (Lelièvre and Derycke, 1998). 
allowed the exploitation of such prey species by shark taxa with crushing and grinding dentitions.

Several morphologically distinct teeth were collected from both the Upper Devonian Gumhole Formation (Protacrodontidae gen. et sp. indet.) and Lower Carboniferous Laurel Formation (Stethacanthus? sp., Ctenacanthiform sp., Hybontoidea sp.). These unique teeth may represent part of a radiation in shark faunas during the Early Carboniferous following the Hangenberg Event (Sallan and Coates, 2010). The notion of an endemic shark fauna is not unusual, as some Late Devonian shark species are known only from the Canning Basin (Trinajstic and George, 2009; Trinajstic et al., 2014, Roelofs et al., 2015). In addition, several known species, including some Frasnian phoebodonts, show unusual degrees of morphological variation in north-west Australia (Trinajstic and George, 2009; Roelofs et al., 2015). It is possible such unusual variations within species may be directly correlated to the depositional environment. For example, the sampling of Famennian and Tournaisian facies that are representative of a shallow water environment in the Carnarvon and Canning basins (Trinajstic et al., 2014; Roelofs et al., 2015; this work) likely explains the absence of the cosmopolitan genus Jalodus, which is typically associated with deeper water pelagic facies across Laurussia and North Gondwana. Further studies on contemporaneous shallow marine platforms in North and East Gondwana are required to determine if some of the species from the Canning Basin represent localised endemism or are constrained by ecological and/or environmental factors.

\section{Faunal Provinces and Biogeography}

Cosmopolitanism in Palaeozoic shark faunas has been recorded as early as the Givetian (Lebedev and Zakharenko, 2010; Potvin-Leduc et al., 2015), with the distributions of many taxa increasing towards the end of the Devonian (Lebedev and Zakharenko, 2010). The Canning Basin contains several elements of these Devonian cosmopolitan shark faunas, including representatives from the phoebodont, cladodont and protacrodont groups, from both the Frasnian (Trinajstic and George, 2009; Trinajstic et al., 2014) and Famennian (Roelofs et al., 2015) (Figure 8.1). The presence of Thrinacodus ferox and Protacrodus aequalis in this work demonstrates this cosmopolitan component continues from the Late Devonian into the Carboniferous (Figure 8.2). Shark taxa with more geographically restricted distributions, such as Deihim mansureae and Protacrodus sp., are found in the Canning Basin (Figure 6.2-4) and Iran (Habibi and Ginter 2011, plate 2B) and indicate close faunal ties between the Canning Basin and other regions to the west in the Late Devonian (Figure 8.1). Further evidence for a faunal exchange along the northern Gondwana shelf is provided by the presence of Thrinacodus ferox (see Trinajstic et al., 2014) and Cladodoides cf. wildungensis (Figure 4.9-12), which closely resemble a tooth identified as Stethacanthus thomasi from north-western Iran (Hampe, 2000). Faunal links with East Gondwana are demonstrated by teeth determined as Cladodus thomasi which, given the revised diagnosis, have only been recorded from the Canning Basin and Rockhampton in Queensland (Turner, 1982). Shark species such as Deihim mansureae (also recovered from the Moogooree Limestone [Trinajstic et al., 2014]), Protacrodus sp. 1 and Cladodus thomasi, from different parts of Gondwana suggests the Canning Basin lay at a junction between biogeographic regions to the east and west.

Late Devonian chondrichthyan taxa including Phoebodus bifurcates Ginter and Ivanov, 1992, Phoebodus fastigatus Ginter and Ivanov, 1992, Thrinacodus tranquillus Ginter, 2000 and Protacrodus serra Ginter et al., 2002 co-occurred within South China and the Canning Basin (Figure 8.1; Trinajstic and George, 2009; Trinajstic et al., 2014; Roelofs et al., 2015). By the Early Carboniferous the shallow water faunal link appears to have been reduced, however, the pelagic component represented by taxa such as Thrinacodus bicuspidatus (see Edwards, 1997; Trinajstic et al., 2014) and Thrinacodus ferox continues between western Australia and South China (Ginter and Sun, 2007). It appears the pelagic sharks species were not as affected by the separation of the Gondwanan and South China landmasses, whereas by the Tournaisian, there was little overlap between the shallow water chondrichthyan species. This is not unexpected, as previous studies (Metcalfe, 1988, 1998) noted the lack of plant and faunal similarities between Lower Carboniferous Gondwanan sections in South China and Australia. The reduced faunal overlap in shallow water chondrichthyan species appears to support a geographic separation between Gondwana and South China because of the northward migration of the South China terrane (Figure 8; Scotese and McKerrow, 1990; Golonka et al., 1994; Metcalfe, 1994); however, as noted above, it is difficult to determine isolated teeth of the crushing morphotype to a species level and therefore more species may await recognition. 


\section{CONCLUSIONS}

The reported chondrichthyan fauna from the Tournaisian of the Lennard Shelf, Canning Basin, is diverse with 16 species identified from shallow marine platform facies. The position of the Canning Basin in the Early Carboniferous, adjacent to northern and eastern Gondwana, allows the investigation of faunal migration and exchange along this ancient continental margin during the recovery phase in the aftermath of significant Late Devonian mass extinctions. The similarities in shark fauna from the Late Devonian between the Canning Basin and North Gondwana are found here to continue into the Carboniferous. In contrast to the Famennian, the north western Australian Tournaisian shark fauna only shows pelagic species similarities with the South China faunas. Despite a limited number of species in common with South China, there is a high degree of similarity in tooth forms within faunas from the shallow water platform at Muhua and the facies analysed in this study. This study also supports the application of the microvertebrate biofacies scheme, established by Ginter (2000) in late Famennian strata, to the Early Carboniferous, at least in shallow water depositional environments.

\section{ACKNOWLEDGEMENTS}

We thank A. Ivanov, Department of Palaeontology, St. Petersburg University and S. Turner from the Queensland Museum for their assistance in the preparation of this work and J. Maisey from the Natural History Museum in New York for his useful comments and access to the collections. We would also like to acknowledge the constructive comments and suggestions from two anonymous reviewers. The authors acknowledge the use of equipment, scientific and technical assistance of the Curtin University Electron Microscope Facility, which has been partially funded by the University, State and Commonwealth Governments. In addition, we thank the owners of Brooking Springs and Laurel Downs stations for allowing access to outcrops. BR recognises the receipt of an Australian Postgraduate Award. This research was funded under Australian Research Council grant DP 110101127. AJM publishes with the permission of the Director, Geological Survey of Western Australia.

\section{REFERENCES}

Agassiz, J.L.R. 1833-1844. Recherches sur les Poissons Fossiles. Petitpierre, Neuchâtel. (In French)
Anderson, L.I. 2009. First non-calcified dasycladalean alga from the Carboniferous. Neues Jahrbuch für Geologie und Paläontologie-Abhandlungen, 251:119128.

Andrew, A., Hamilton, P., Mawson, R., Talent, J., and Whitford, D. 1994. Isotopic correlation tools in the mid-Palaeozoic and their relation to extinction events. Australian Petroleum Exploration Association Journal, 34:268-277.

Becker, R. and House, M. 2009. Devonian ammonoid biostratigraphy of the Canning Basin. Geological Survey of Western Australia, Bulletin, 145:415-439.

Behan, C., Walken, G., and Cuny, G. 2012. A Carboniferous chondrichthyan assemblage from residues within a Triassic karst system at Cromhall Quarry, Gloucestershire, England. Palaeontology, 55:1245-1263.

Boessenecker, R.W., Perry, F.A., and Schmitt, J.G. 2014. Comparative taphonomy, taphofacies, and bonebeds of the Mio-Pliocene Purisima Formation, central California: Strong physical control on marine verterbate preservation in shallow marine settings. PLOS ONE, 9:e91419.

Bonaparte, C.L.J.L. 1831. Saggio di una distribuzione metodica degli animali vertebrati. Giornale Arcadico di Scienze, 49:1-77. (In Italian)

Bonaparte, C.L.J.L. 1832-1838. Selachorum tabula analytica. Nuovi Annali delle Scienze Naturali, 1:195214. (In Latin)

Broom, R. 1909. The fossil fishes of the upper Karroo beds of South Africa. Annals of the South African Museum, 7:251-269.

Brough, J. 1935. On the structure and relationships of the hybodont sharks. Memoirs and Proceedings of the Manchester Literary and Philosophical Society, 79:35-50.

Burrow, C.J., Turner, S., and Young, G.C. 2010. Middle Palaeozoic microvertebrate assemblages and biogeography of East Gondwana (Australasia, Antarctica). Palaeoworld, 19:37-54.

Cappetta, H., Duffin, C., and Zidek, J. 1993. Chondrichthyes, p. 593-609. In Benton, M.J. (ed.), The Fossil Record 2. Chapman and Hall, London.

Dean, B. 1909. Studies on fossil fishes (sharks, chimaeroids and arthrodires). American Museum of Natural History Memoir, 9:211-287.

Delsate, D., Smet, F., and Wille, E. 2003. New ichthyoliths from the Lower Carboniferous of Belgium. Ferrantia, 36:29-38.

Derycke, C. 1992. Microrestes de Selaciens et autres Vertébres du Dévonien superieur de Maroc. Bulletin du Muséum National d'Histoire Naturelle. Paris $4 e$ series, 14:15-61. (In French)

Derycke-Khatir, C. 2005. Microrestes de vertébrés du Paléozöique supérieur de la Manche au Rhin. Société Géologique du Nord Publication, 33:1-261. (In French)

Derycke, C., Spalletta, C., Perri, M.C., and Corradini, C. 2008. Famennian chondrichthyan microremains from 
Morocco and Sardinia. Journal Information, 82:984995.

Downs, J.P. and Daeschler, E.B. 2001. Variation within a large sample of Ageleodus pectinatus teeth (Chondrichthyes) from the Late Devonian of Pennsylvania, USA. Journal of Vertebrate Paleontology, 21:811814.

Druce, E.C. and Radke, B. 1979. The geology of the Fairfield Group, Canning Basin, Western Australia, 200. Australian Government Public Service, Canberra, Australia.

Duffin, C.J. 1985. Revision of the hybodont selachian genus Lissodus Brough (1935). Palaeontographica Abteilung A, 188:105-152.

Duffin, C.J. and Ginter, M. 2006. Comments on the selachian genus Cladodus Agassiz, 1843. Journal of Vertebrate Paleontology, 26:253-266.

Duncan, M. 2003. Early Carboniferous chondrichthyan Thrinacodus from Ireland, and a reconstruction of jaw apparatus. Acta Palaeontologica Polonica, 48:113122.

Duncan, M. 2004. Chondrichthyan genus Lissodus from the Lower Carboniferous of Ireland. Acta Palaeontologica Polonica, 49:417-428.

Eastman, C.R. 1897. Tamiobatis vetustus; a new form of fossil skate. American Journal of Science, 20:85-90.

Edgell, H.S. 2004. Upper Devonian and Lower Carboniferous Foraminifera from the Canning Basin, Western Australia. Micropaleontology, 50:1-26.

Edwards, A.F. 1997. Ichthyolith remains from the Devonian-Carboniferous Boundary of the Canning Basin, Western Australia. Unpublished MSc thesis, School of Earth Sciences, Macquarie University, Sydney, Australia.

Fischer, J. 2008. Brief synopsis of the hybodont form taxon Lissodus Brough, 1935, with remarks on the environment and associated fauna. Freiberger Forschungshefte $C, 528: 1-23$.

Garvey, J.M. and Turner, S. 2006. Vertebrate microremains from the presumed earliest Carboniferous of the Mansfield Basin, Victoria. Alcheringa, 30:43-62.

Ginter, M. 1990. Late Famennian shark teeth from the Holy Cross Mountains, Central Poland. Acta Geologica Polonica, 40:69-81.

Ginter, M. 1994. Ichtiolity dewońskie z Polski i Uralu oraz ich znaczenie stratygraficzne. Unpublished Ph.D. thesis, Warsaw University, Warsaw, Poland. (In Polish)

Ginter, M. 1999. Famennian-Tournaisian chondrichthyan microremains from the eastern Thuringian Slate Mountains. Abhandlungen und Berichte für Naturkunde, 21:25-47.

Ginter, M. 2000. Late Famennian pelagic shark assemblages. Acta Geologica Polonica, 50:369-386.

Ginter, M. 2001. Chondrichthyan biofacies in the Late Famennian of Utah and Nevada. Journal of Vertebrate Paleontology, 21:714-729.
Ginter, M. 2002. Chondrichthyan fauna of the FrasnianFamennian boundary beds in Poland. Acta Palaeontologica Polonica, 47:329-338.

Ginter, M., Hairapetian, V., and Grigoryan, A. 2011. Chondrichthyan microfossils from the Famennian and Tournaisian of Armenia. Acta Geologica Polonica, 61:153-173.

Ginter, M., Hairapetian, V., and Klug, C. 2002. Famennian chondrichthyans from the shelves of North Gondwana. Acta Geologica Polonica, 52:169-215.

Ginter, M., Hampe, O., and Duffin, C.J. 2010. Paleozoic Elasmobranchii: Teeth, p. 1-168. In Shultze, H.P. (ed.), Handbook of Paleoichthyology, volume 3D. Verlag Dr. Friedrich Pfeil, München, Germany.

Ginter, M. and Ivanov, A. 1992. Devonian phoebodont shark teeth. Acta Palaeontologica Polonica, 37:5575.

Ginter, M. and Ivanov, A. 1996. Relationships of Phoebodus. Modern Geology, 20:263-274.

Ginter, M. and Ivanov, A. 2000. Stratigraphic distribution of chondrichthyans in the Devonian on the East European Platform margin. Courier-Forshungsinstitut Senckenberg, 325-340.

Ginter, M. and Sun, Y. 2007. Chondrichthyan remains from the Lower Carboniferous of Muhua, southern China. Acta Palaeontologica Polonica, 52:705.

Ginter, M. and Turner, S. 1999. The early Famennian recovery of phoebodont sharks. Acta Geologica Polonica, 49:105-117.

Ginter, M. and Turner, S. 2010. The middle Paleozoic Selachian genus Thrinacodus. Journal of Vertebrate Paleontology, 30:1666-1672.

Glenister, B.F. and Klapper, G. 1966. Upper Devonian conodonts from the Canning Basin, Western Australia. Journal of Paleontology, 40:777-842.

Glikman, L. 1964. Class Chondrichthyes, Subclass Elasmobranchii. Osnovy Paleontologii, 11:195-236.

Golonka, J. 2007. Phanerozoic paleoenvironment and paleolithofacies maps: late Palezoic. Geologia/Akademia Górniczo-Hutnicza im. Stanisława Staszica w Krakowie, 33:145-209.

Golonka, J., Ross, M., and Scotese, C. 1994. Phanerozoic paleogeographic and paleoclimatic modeling maps. Canadian Society of Petroleum Geologists, 17:1-47.

Habibi, T. and Ginter, M. 2011. Early Carboniferous chondrichthyans from the Mobarak Formation, Central Alborz Mountains, Iran. Acta Geologica Polonica, 61:27-34.

Habibi, T., Yazdi, M., Zarepoor, S., and Parvanehnejad Shirazi, M. 2013. Late Devonian fish micro-remains from Central Iran. Geopersia, 3:25-34.

Hairapetian, V. and Ginter, M. 2009. Famennian chondrichthyan remains from the Chahriseh section, central Iran. Acta Geologica Polonica, 59:173-200.

Hairapetian, V. and Ginter, M. 2010. Pelagic chondrichthyan microremains from the Upper Devonian of the Kale Sardar section, eastern Iran. Acta Geologica Polonica, 60:357-371. 
Hairapetian, V., Roelofs, B.P., Trinajstic, K.M., and Turner, S. 2015. Famennian survivor turiniid thelodonts of North and East Gondwana. Geological Society, London, Special Publications, 423. doi:10.1144/SP423.3

Hampe, O. 2000. Occurrence of Phoebodus gothicus (Chondrichthyes: Elasmobranchii) in the middle Famennian of northwestern Iran (Province East Azerbaijan). Acta Geologica Polonica, 50:355-367.

Hay, O.P. 1902. Bibliography and catalogue of the fossil Vertebrata of North America. Bulletin, United States Geological Survey, 179:1-868.

Herman, J. 1977 (date of imprint 1975). Les Sélaciens de Terrains Néocrétacés et Paléocènes de Belgique et des Contreés Limitrophes Elements d'une Biostratigraphie Intercontinental. Mémoires pour servir à l'explication des Cartes géologiques et minières de la Belgique, 15. Service Geologique de Belgique, Brussels. (In French).

Hill, D. 1954. Coral faunas from the Silurian of New South Wales and the Devonian of Western Australia. Bureau of Mineral Resources Geology and Geophysics, 23:1-51.

Hocking, R.M., Playford, P.E., Haines, P.W., and Mory, A.J. 2008. Paleozoic Geology of the Canning Basin A Field Guide. Geological Survey of Western Australia, Perth, Australia.

Huddle, J.W. 1934. Conodonts from the New Albany Shale of Indiana. Bulletins of American Paleontology, 21:1-136.

Huxley, T.H. 1880. On the application of the laws of evolution to the arrangement of the Vertebrata, and more particularly of the Mammalia. Proceedings of the Zoological Society, London, 43:649-662.

Ivanov, A. 1996. The Early Carboniferous chondrichthyans of the South Urals, Russia. Geological Society, London, Special Publications, 107:417-425.

Ivanov, A. 1999. Late Devonian-Early Permian chondrichthyans of the Russian Arctic. Acta Geologica Polonica, 49:267-285.

Ivanov, A.O. and Lucas, S.G. 2011. Paleozoic Sly Gap Formation of southern New Mexico, USA. New Mexico Museum of Natural History and Science Bulletin, 53:52-70

Ivanov, A.O. and Lukševičs, E. 1994. Famennian chondrichthyans from the Main and Central Devonian Fields. Daba un muzejs, 5:24-29.

Jaekel, O. 1921. Die Stellung der Paläontologie zur einigen Problemen der Biologie und Phylogenie. Schadelprobleme. Paläontologische Zeitschrift, 3:213239. (In German)

Jaekel, O. 1925. Das Mundskelett der Wirbeltiere. Gegenbaurs Morphologishes Jahrbuch, 55:402-409. (In German)

Janvier, P. 1996. Early Vertebrates, 33. Clarendon Press, Oxford.

Jeppsson, L., Anehus, R., and Fredhold, D. 1999. The optimal acetate buffered acetic acid technique for extracting phosphatic fossils. Journal of Paleontology, 73:964-972.

Jones, P. 1959. Preliminary report on Ostracoda from Bore BMR No. 2, Laurel Downs, Fitzroy Basin, Western Australia. Bureau of Mineral Resources, Australian Geology and Geophysics, 38:17-52.

Jones, P.J, 1974. Australian Devonian and Carboniferous (Emsian Visean) ostracod faunas: a review, p. 119. In Bouckaert, J. and Streel, M. (eds.), International Symposium on Belgian Micropaleontological Limits from Emsian to Visean, Namur, 1974. Geological Survey of Belgium, Brussels, Belgium.

Jones, P. 1987. Rhytiobeyrichia, a new beyrichiacean ostracod from the late Devonian of Western Australia. Bureau of Mineral Resources, Australian Geology and Geophysics, 10:287-300.

Jones, P. 1995. Timescales 5, Carboniferous. Australian Phanerozoic timescales, biostratigraphic charts and explanatory notes. Australian Geological Survey Organisation Record 1995/34, Canberra, Australia.

Jones, P. and Thomas, G.A. 1959. Preliminary report on probable Lower Carboniferous fossils from Station Creek area, Fitzroy Basin, (Westralian Oil Limited, Permite 106H). Record 1959/094, Bureau of Mineral Resources, Geology and Geophysics, Canberra, Australia.

Kietzke, K. and Lucas, S. 1992. Ichthyoliths from the Devonian-Carboniferous Boundary in the Sacramento Mountains, South Central New Mexico, USA. Ichthyolith issues, 8:17-21.

Klapper, G. 2007. Frasnian (Upper Devonian) conodont succession at Horse Spring and correlative sections, Canning Basin, Western Australia. Journal of Paleontology, 81:513-537.

Kosnik, M.A., Alroy, J., Behrensmeyer, A.K., Fürsich, F.T., Gastaldo, R.A., Kidwell, S.M., Kowalewski, M., Plotnick, R.E., Rogers, R.R., and Wagner, P.J. 2011. Changes in shell durability of common marine taxa through the Phanerozoic: evidence for biological rather than taphonomic drivers. Paleobiology, $37: 303-331$.

Lebedev, O. 1996. Fish assemblages in the TournaisianViséan environments of the East European Platform. Geological Society, London, Special Publications, 107:387-415.

Lebedev, O. and Zakharenko, G. 2010. Global vertebrate-based palaeozoogeographical subdivision for the Givetian-Famennian (Middle-Late Devonian): Endemism-cosmopolitanism spectrum as an indicator of interprovincial faunal exchanges. Palaeoworld, 19:186-205

Lelièvre, H. and Derycke, C. 1998. Microremains of vertebrate near the Devonian-Carboniferous boundary of southern China (Hunan province) and their biostratigraphical significance. Revue de Micropaléontologie, 41:297-320.

Long, J.A. 1989. A new rhizodontiform fish from the Early Carboniferous of Victoria, Australia, with 
remarks on the phylogenetic position of the group. Journal of Vertebrate Paleontology, 9:1-17.

Long, J.A. and Hairapetian, V. 2000. Famennian microvertebrates from the Dalmeh area, central Iran. Records of the Western Australian Museum, Supplement, 58:211-221.

Lund, R. 1974. Stethacanthus altonensis (Elasmobranchii) from the Bear Gulch Limestone of Montana. Annals of the Carnegie Museum, 45:43-56.

Lund, R. and Grogan, E.D. 1997. Relationships of the Chimaeriformes and the basal radiation of the Chondrichthyes. Reviews in Fish Biology and Fisheries, 7:65-123.

Metcalfe, I. 1988. Origin and assembly of south-east Asian continental terranes. Geological Society, London, Special Publications, 37:101-118.

Metcalfe, I. 1994. Gondwanaland origin, dispersion, and accretion of East and Southeast Asian continental terranes. Journal of South American Earth Sciences, 7:333-347.

Metcalfe, I. 1998. Palaeozoic and Mesozoic geological evolution of the SE Asian region: multidisciplinary constraints and implications for biogeography, p. 2541. In Hall, R. and Holloway, J.D. (eds.), Biogeography and Geological Evolution of SE Asia. Backhuys Publishers, Amsterdam, Netherlands.

Metcalfe, I. 2011. Palaeozoic-Mesozoic history of SE Asia. Geological Society, London, Special Publications, 355:7-35.

Mory, A.J. and Hocking, R.M. 2011. Permian, Carboniferous and Upper Devonian Geology of the Northern Canning Basin, Western Australia: A Field Guide. Geological Survey of Western Australia, Perth, Australia.

Newberry, J.S. 1889. The Paleozoic fishes of North America. U.S. Geological Survey, Monograph, 16:1340.

Newberry, J.S. and Worthen, A.H. 1866. Descriptions of new species of vertebrates, mainly from the Sub-Carboniferous Limestone and Coal Measures of Illinois. Geological Survey of Illinois, 2:9-134.

Nicoll, R.S. and Druce, E.C. 1979. Conodonts from the Fairfield Group, Canning Basin, Western Australia. Bureau of Mineral Resources Australia Bulletin. 190:1-134.

Owen, R. 1846. Lectures on the Comparative Anatomy and Physiology of the Vertebrate Animals: Delivered at the Royal College of Surgeons of England in 1844 and 1846, 1. Longman, Brown, Green, and Longmans.

Owen, R. 1867. On the mandible and mandibular teeth of cochliodonts. Geological Magazine, 4:59-63.

Playford, P.E. 1976. Devonian Reef Complexes of the Canning Basin, Western Australia. 25th International Geological Congress, Excursion Guide No. 38A, Sydney, Australia.

Playford, P.E., Hocking, R.M., and Cockbain, A.E. 2009. Devonian reef complexes of the Canning Basin, WA.
Bulletin of the Geological Survey of Western Australia, 145:1-444.

Potvin-Leduc, D., Cloutier, R., Landing, E., Hernick, L.V., and Mannolini, F. 2015. Givetian (Middle Devonian) sharks from Cairo, New York (USA): Evidence of early cosmopolitanism. Acta Palaeontologica Polonica, 60:183-200.

Rhodes, F.H.T., Austin, R.L., and Druce, E.C. 1969. British Avonian (Carboniferous) conodont faunas and their value in local and intercontinental correlation. Bulletin of the British Museum (Natural History), Geology Supplement, 5:1-313.

Roelofs, B., Playton, T., Barham, M., and Trinajstic, K. 2015. Upper Devonian microvertebrates from the Canning Basin, Western Australia. Acta Geologica Polonica, 65:69-101.

Ross, J.P. 1961. Ordovician, Silurian and Devonian Bryozoa of Australia. Bureau of Mineral Resources Australia, Bulletin, 50:1-172.

Sallan, L.C. and Coates, M.I. 2010. End-Devonian extinction and a bottleneck in the early evolution of modern jawed vertebrates. Proceedings of the National Academy of Sciences, 107:10131-10135.

Scotese, C.R. and McKerrow, W.S. 1990. Revised world maps and introduction. Geological Society, London, Memoirs, 12:1-21.

Seilacher, A. 1943. Elasmobranchier-Reste aus dem oberen Muschelkalk und dem Keuper Württembergs. Neues Jahrbuch für Mineralogie, Geologie und Paläontologie, Monatshefte B, 1943:256-292. (In German)

Southgate, P.N., Kennard. J.M., Jackson, M.J., O'Brien, P.E., and Sexton, M.J. 1993. Reciprocal lowstand clastic and highstand carbonate sedimentation, subsurface Devonian reef complex, Canning Basin, Western Australia, p. 157-159. In Loucks, R.G. and Sarg, J.F. (eds.), Carbonate Sequence Stratigraphy, Recent Developments and Applications. American Association of Petroleum Geologists Memoir 57. Tulsa, Oklahoma, USA.

St. John, O. and Worthen, A. 1875. Descriptions of fossil fishes. Geological Survey of Illinois, 6:245-488.

Teichert, C. 1949. Stratigraphy and palaeontology of Devonian portion of Kimberley Division, Western Australia. Australia Bureau of Mineral Resources, Geology and Geophysics, 2:1-50.

Thomas, G.A. 1957. Lower Carboniferous deposits in the Fitzroy Basin, Western Australia. The Australian Journal of Science, 19:160-161.

Thomas, G.A. 1959. The Lower Carboniferous Laurel Formation of the Fitzroy Basin. Bureau of Mineral Resources, Report, 38:31-36.

Thomas, G.A. 1971. Carboniferous and early Permian brachiopods from Western and Northern Australia. Bureau of Mineral Resources, Geology and Geophysics Australia, Bulletin. 56:1-276.

Trautschold, H. 1874. Die Kalkbrüche von Mjatschkowa. Eine Monographie des oberen Bergkalks. Erste Hälfte.Nouveaux mémoires de la Société impériale 
des naturalistes de Moscou, 13:277-326. (In German)

Trinajstic, K. 2001. A description of additional variation seen in the scale morphology of the Frasnian thelodont Australolepis seddoni Turner and Dring, 1981. Records of the Western Australian Museum, 20:237-246.

Trinajstic, K. and George, A.D. 2009. Microvertebrate biostratigraphy of Upper Devonian (Frasnian) carbonate rocks in the Canning and Carnarvon basins of Western Australia. Palaeontology, 52:641-659.

Trinajstic, K., Roelofs, B., Burrow, C., Long, J., and Turner, S. 2014. Devonian vertebrates from the Canning and Carnarvon Basins with an overview of Paleozoic vertebrates of Western Australia. Journal of the Royal Society of Western Australia, 97:133151.

Turner, S. 1982. Middle Palaeozoic elasmobranch remains from Australia. Journal of Vertebrate Paleontology, 2:117-131.

Turner, S. 1991. Palaeozoic Vertebrate Microfossils in Australasia, p. 429-464. In Vickers-Rich, P., Monaghan, J.M., Baird, R.F., and Rich, T.H. (eds.), Vertebrate Palaeontology of Australasia. Monash University Publications Committee, Melbourne.

Turner, S. 1993. Early Carboniferous microvertebrates from the Narrien Range, central Queensland. Memoirs of the Association of Australasian Palaeontologists, 15:289-304.

Turner, S. and Dring, R.S. 1981. Late Devonian thelodonts (Agnatha) from the Gneudna Formation, Carnarvon Basin, Western Australia. Alcheringa, 5:39-48.

Veevers, J.J. 1959. Devonian brachiopods from the Fitzroy Basin, Western Australia. Bulletin of the Bureau of Mineral Resources, Geology and Geophysics. 45:1-220.

Wang, S. 1989. Biostratigraphy of vertebrate microfossils, p. 36-38, 103-108. In Ji Q. (ed.), The Daspoushang Section-An Excellent Section for Devonian-Carboniferous Boundary Stratotype in China. Science Press, Beijing.

Wang, S. 1993. Vertebrate biostratigraphy of the Middle Palaeozoic of China, p. 252-276. In Long, J.A. (ed.),
Palaeozoic Vertebrate Biostratigraphy and Biogeography. Belhaven Press, London.

Wang, S. and Turner, S. 1985. A re-appraisal of Upper Devonian-Lower Carboniferous verrtebrate microfossils in South China. Professional Papers of Stratigraphy \& Palaeontology, 26:59-70.

Williams, M.E. 1985. The «cladodont level» sharks of the Pennsylvanian black shales of central North America. Palaeontographica Abteilung A, 83-158.

Williams, M.E. 1998. A new specimen of Tamiobatis vetustus (Chondrichthyes, Ctenacanthoidea) from the late Devonian Cleveland Shale of Ohio. Journal of Vertebrate Paleontology, 18:251-260.

Willmott, S. 1962. Geological report on Frome Rocks No2 Well. Bureau of Mineral Resources, Australia, Petroleum Search Subsidy Acts Publication, 8:15-20.

Yazdi, M. and Turner, S. 2000. Late Devonian and Carboniferous vertebrates from the Shishtu and Sardar formations of the Shotori Range, Iran. Records of the Western Australian Museum, Supplement, 58:223240.

Young, G. 1984. Comments on the phylogeny and biogeography of antiarchs (Devonian placoderm fishes), and the use of fossils in biogeography. Proceedings of the Linnean Society of New South Wales, 107:443-473.

Young, G. 1987. Devonian fish remains from Billiluna, eastern Canning Basin, Western Australia. BMR Journal of Australian Geology and Geophysics, 10:179-192.

Young, G.C. 2010. Placoderms (armored fish): dominant vertebrates of the Devonian Period. Annual Review of Earth and Planetary Sciences, 38:523-550.

Young, G.C., Burrow, C.J., Long, J.A., Turner, S., and Choo, B. 2010. Devonian macrovertebrate assemblages and biogeography of East Gondwana (Australasia, Antarctica). Palaeoworld, 19:55-74.

Zangerl, S. 1981. Paleozoic Elasmobranchii, p. 1-115. In Shultze, H.P. (ed.), Handbook of Paleoichthyology, volume 3A. Gustav Fischer Verlag, Stuttgart, Germany.

Ziegler, W. and Sandberg, C.A. 1990. The Late Devonian standard conodont zonation. Courier Forshungsinstitut Senckenberg, 121:1-115. 